IZA DP No. 10385

Inter-ethnic Fertility Spillovers and the Role of Forward-looking Behavior:

Evidence from Peninsular Malaysia

Emily A. Beam

Slesh A. Shrestha

November 2016 


\title{
Inter-ethnic Fertility Spillovers and the Role of Forward-looking Behavior: Evidence from Peninsular Malaysia
}

\author{
Emily A. Beam \\ University of Vermont \\ and IZA \\ Slesh A. Shrestha \\ National University of Singapore
}

Discussion Paper No. 10385

November 2016

\author{
IZA \\ P.O. Box 7240 \\ 53072 Bonn \\ Germany \\ Phone: +49-228-3894-0 \\ Fax: +49-228-3894-180 \\ E-mail: iza@iza.org
}

\begin{abstract}
Any opinions expressed here are those of the author(s) and not those of IZA. Research published in this series may include views on policy, but the institute itself takes no institutional policy positions. The IZA research network is committed to the IZA Guiding Principles of Research Integrity.

The Institute for the Study of Labor (IZA) in Bonn is a local and virtual international research center and a place of communication between science, politics and business. IZA is an independent nonprofit organization supported by Deutsche Post Foundation. The center is associated with the University of Bonn and offers a stimulating research environment through its international network, workshops and conferences, data service, project support, research visits and doctoral program. IZA engages in (i) original and internationally competitive research in all fields of labor economics, (ii) development of policy concepts, and (iii) dissemination of research results and concepts to the interested public.
\end{abstract}

IZA Discussion Papers often represent preliminary work and are circulated to encourage discussion. Citation of such a paper should account for its provisional character. A revised version may be available directly from the author. 


\section{ABSTRACT \\ Inter-ethnic Fertility Spillovers and the Role of Forward-looking Behavior: Evidence from Peninsular Malaysia*}

Demographic pressures can create competition for limited private and public resources and exacerbate pre-existing inter-ethnic tensions. At the same time, inter-ethnic competition may influence individual fertility decisions. Using the variation in birth rates in Malaysia induced by the Chinese lunar calendar, we document a 12.7-percent rise in births among ethnic Chinese in dragon years, which are considered auspicious. We find a negative fertility response from Malays - for every additional Chinese new-born child, Malays reduced their fertility by 0.30 children. We estimate the elasticity of this inter-ethnic fertility spillover $(-0.15)$, and we find strongly suggestive evidence that pressure on resources was an important driver of these spillovers. The Malay response was greatest in areas where resources were more limited, and in areas with lower public investments. These results suggest that households are forward-looking in their fertility decisions, and they point to the potential role of governments in reducing ethnic tension through policies that increase private and public resources.

JEL Classification: D74, J13, J15, O15, O17

Keywords: fertility timing, ethnic competition, spillover, Chinese zodiac, public resources, Malaysia

Corresponding author:

Emily A. Beam

Department of Economics

University of Vermont

233 Old Mill

Burlington, VT 05405

USA

E-mail: emily.beam@uvm.edu

\footnotetext{
* Financial support for this research was provided by the $\mathrm{J} Y$ Pillay Comparative Asia Research Centre, National University of Singapore Global Asia Institute. We are grateful to seminar participants at the National University of Singapore for their helpful comments and suggestions and to Ruijie Tan, who provided outstanding research assistance.
} 


\section{NON-TECHNICAL SUMMARY}

In ethnically diverse societies, changes in demographic structures, such as shifts in the size and composition of cohorts, can put pressure on resources such as health care and education and worsen ethnic tensions. However, ethnic tension itself may also affect whether and when people have children. We use a natural experiment in Peninsular Malaysia created by changes in the Chinese lunar calendar to measure how Malays respond to temporary Chinese baby "booms." We find that, from 1970-1990, Chinese birth rates rise by 13 percent in auspicious dragon years, leading to an additional 26,000 births. In those same years, Malay birth rates fall by 2 percent, leading to 8,000 fewer births.

We also find that this drop in birth rates by Malays is greatest in areas with a high Chinese concentration, with more limited resources, and with less government investment. Perhaps as a result of increased pressure on resources, we also find that Malays experience higher stillbirth and infant death rates in dragon years. It appears that household are making their fertility decisions with an eye toward the future, deciding not to have children in dragon years when the short-term cost of doing so is especially high and the long-term benefits may be less due to increased competition. These results also suggest that governments may be able to reduce ethnic tension through policies that increase access to resources. 


\section{Introduction}

Ethnic heterogeneity can affect the formation of states and their institutions, thus determining the economic outcomes of their citizens (Easterly and Levine, 1997; Alesina et al., 1999; Alesina and Ferrara, 2005). At the same time, state institutions may try to address ethnic tensions, which are associated with ethnic heterogeneity (Esteban and Ray, 2011; Esteban et al., 2012), by determining the magnitude of public investments and deciding how these resources are targeted. When such institutions are weak, individual-level responses to inter-ethnic competition can play a primary role in mitigating ethnic tensions. In this paper, we study inter-ethnic interactions in the form of fertility spillovers between Malay and Chinese ethnic groups in Malaysia, and we examine the relationship of these spillovers to the competition for resources that affect child outcomes.

Becker (1991), among others, postulates that families adjust their fertility in response to anticipated economic shocks to maximize their expected returns from childbearing. Nevertheless, adjusting fertility timing in response to a greater burden on public resources exerted by other ethnic groups requires a substantial degree of forward-looking behavior. The state can also influence the scale of inter-ethnic fertility spillovers by improving the availability of public (and private) resources in general or for a selected ethnic group.

The empirical evidence on such inter-ethnic spillovers is scarce, however, because causal identification requires an exogenous source of variation in the birth rate of one ethnic group that is uncorrelated with the birth rate of other groups. We identify one such variation, in the form of changes in fertility preferences over the Chinese lunar calendar, in the ethnically diverse region of Peninsular Malaysia. The Malay ethnic group comprises the majority of this region's population (65 percent), while ethnic Chinese, who represent the largest minority, make up one quarter of the population. This ethnic heterogeneity in part comes from the legacy of British colonial rule, under which there was a substantial flow of Chinese immigrants into Malaysia along with explicit economic segregation across ethnic lines. Since its independence, the Malaysian government has made concerted policy efforts to allocate resources to aid the Malay population, which was historically disadvantaged relative to the Chinese, through ethnic-based quotas in higher education and public employment, along with preferential treatment for Malays in access to credit and ownership of business assets 
(Faaland et al., 2003).

In this context, we focus on the increase in Chinese births that occurs in the lunar Year of the Dragon, believed to be an auspicious year of birth by Chinese in Malaysia. Malays, on the other hand, do not adhere to this belief. This makes it an ideal case through which to study inter-ethnic spillovers on Malay fertility and to examine the role of public resources and policies on fertility decisions and ethnic tensions.

Using newly digitized district-level data that span two decades (1970-1990) from the Malaysian Vital Statistics, we find that birth rates among ethnically Chinese Malaysians rose by 12.7 percent in dragon years (1976 and 1989). In contrast, ethnic Malays reduced their fertility by 2.0 percent in dragon years. The elasticity of Malay birth rates relative to Chinese birth rates is -0.15 , and this lunar-year shock led to a net 2.5 percent increase in size and a 8.4 percent change in ethnic composition of each dragon-year cohort.

Moreover, the negative Malay fertilizer response was larger in Chinese-majority areas and in areas with relatively fewer public resources and investment. These results suggest that increased competition for resources brought on by the change in cohort size and composition was an important driver of the fertility spillovers we observe. The decline in fertility by Malays, and the differential response across districts with varying resource levels, is perhaps not surprising because we also find an increase in under- 1 mortality rates among Malay children born in dragon years.

Our results contribute to several strands of literature. Ethnic heterogeneity, both across and within countries, is often associated with lower levels of public goods provision (Alesina et al., 1999; Banerjee et al., 2005; Miguel and Gugerty, 2005), higher levels of political corruption and conflict (Montalvo and Reynal-Querol, 2005; i Miquel, 2007; Esteban and Ray, 2011; Esteban et al., 2012), and worse economic performance (Easterly and Levine, 1997; Alesina and Ferrara, 2005). This heterogeneity can encourage citizens to sort into their respective group, first suggested by Tiebout (1956) as a solution, at least in theory, to the collective action failure and the heterogeneous preference problem associated with ethnic diversity. Many empirical studies have found evidence of self-segregation, mostly in terms of residential location and school choices, following increased inter-ethnic interaction (Fairlie and Resch, 2002; Card et al., 2008; Brunner et al., 2010; Baum-Snow and Lutz, 2011). ${ }^{1}$ The

\footnotetext{
${ }^{1}$ Baum-Snow and Lutz (2011) find an increase in ethnic resorting of households, with whites moving out
} 
impacts of segregation, however, have mostly been negative (Boeri et al., 2015; Hsieh et al., 2013; Douglas et al., forthcoming), ${ }^{2}$ and in particular, segregation has been shown to worsen ethnic inequality in education and healthcare (Card and Rothstein, 2007; Rahman and Foster, 2015). In Malaysia, we find evidence of self-sorting across birth cohorts through differential changes in annual birth rates between Malays and Chinese across the Chinese lunar calendar. This sorting could also have serious implications for individual outcomes and ethnic inequality through the lifecycle.

Cohort size affects economic outcomes throughout the different stages of life, in some cases due to greater burden on resources (Bound and Turner, 2007; Saavedra, 2012; Reiling, 2016) and due to differential selection into childbearing (Chevalier and Marie, forthcoming). In ethnically diverse or economically unequal societies, increased competition faced in larger cohorts can disproportionately affect poor households because increased competition often takes resources away from the most vulnerable groups (Besley et al., 2012; Gupta, 1987), and these households lack private resources to compensate for early-life negative shocks (Fairlie and Resch, 2002). Our results show that one way that households attempt to protect themselves from anticipated competition is through adjusting their fertility timing.

Our results also relate to a large literature on the economics of fertility decisions (Becker and Lewis, 1973; Becker, 1991). Just as families may weigh quantity-quality trade-offs to maximize the expected returns to childbearing, they may also aim to optimize the timing of their fertility decisions. Researchers have observed small movements in fertility timing in response to monetary incentives and tax benefits (for example, Dickert-Conlin and Chandra (1999); Gans and Leigh (2009); Turner (2014)) and school-entry age criteria (Deming and Dynarski, 2008). The evidence around fertility timing at the point of conception is more limited, and it includes research regarding tax incentives and public policies (Kureishi and Wakabayashi, 2008; Lichtman-Sadot, 2014), seasonal labor market returns (Artadi, 2005), and religious practices (Karimova, 2015). Our paper finds that demographic pressures can

of inner cities and a decline in white public school enrollment following school desegregation in the United States. Using Census track data from 1970 to 2000, Card et al. (2008) find that white migration in most U.S. cities exhibits tipping-like behavior, with the distribution of tipping points ranging from a 5- to 20-percent minority share. Fairlie and Resch (2002) find strong evidence of "white flight" from public to private schools in areas with larger concentrations of poor black children. Brunner et al. (2010) show that white households are more likely to support vouchers that expand school choices when their children attend schools with a larger minority concentration, suggesting their preference for ethnically segregated schools.

${ }^{2}$ On the other hand, Kerr and Mandorff (2015) find that sorting among immigrants can create a comparative advantage through occupational stratification. 
also influence fertility timing at the point of conception, as families strategically avoid giving birth in years in which larger cohort sizes and a different ethnic composition place an additional burden on resources.

Lastly, a small body of literature uses superstition as a source of exogenous variation in fertility, which can affect sex ratios (Lee and Paik, 2006), parents' investments in children (Do and Phung, 2010), children's outcomes (Johnson and Nye, 2011; Lau, 2015), and parents' outcomes (Vere, 2008) in the Chinese diaspora across different countries. To our knowledge, this is the first paper that examines the spillover effects of these fertility responses onto members of non-Chinese groups.

\section{Background}

\subsection{Political economy of Malaysia}

Malaysia is an ethnically diverse country. Two-thirds of the population is bumiputera ("sons of the soil"), which includes the Malay ethnic group along with smaller non-Malay indigenous groups. ${ }^{3}$ Chinese form the largest minority group, making up nearly 25 percent of the population, and the remainder are Indian or members of other ethnic groups (Department of Statistics, 2015).

The present-day ethnic heterogeneity in part reflects the heritage of British colonial rule in Malaysia. Under British rule, the government allowed large-scale Chinese immigration into Malaysia in order to ensure a continuous supply of labor to the booming tin mines that drove trade in the Straits Settlements (Purcell, 1948; Blythe, 1947). Areas with large Chinese settlements eventually became important urban centers, and many became state capitals as well (Wong, 1965). Apart from its impact on ethnic composition, the policy also meant that ethnic identity played a crucial role in determining where individuals lived and what jobs they held. By 1957, the year Malaysia obtained independence, the Chinese were slightly wealthier, working as merchants and traders and living primarily in urban areas, while the majority Malay population was poorer, more rural, and working primarily

\footnotetext{
${ }^{3}$ We refer to all of the ethnic groups (Malays and non-Malay indigenous groups) classified as bumiputera as "Malays." In Peninsular Malaysia, the Malay ethnic group accounts for 98.5 percent of bumiputera.
} 
in agriculture (Department of Statistics, 1958, 1959).

After independence, Malays were afforded explicit protections in the new constitution in exchange for citizenship for Chinese and Indian residents. The New Economic Policy (NEP)-introduced after the race riots in Kuala Lumpur in 1969-set out explicit aims to (1) "eradicate poverty irrespective of race" and (2) "restructure society to abolish the identification of race with economic function" (Government of Malaysia, 1971). In practice, the NEP aimed to redress the economic position of the Malays relative to the non-Malays, and it became the central aspect of the government's development agenda under four successive five-year Malaysia Plans from 1971 to 1990 (Faaland et al., 2003). The NEP introduced quotas in higher education and public employment for Malays, set targets for Malay ownership share of private equities, and encouraged Malay employment in modern sectors such as manufacturing, mining, commerce, and construction, which were identified as initially having low Malay participation (Government of Malaysia, 1976; Means, 1986; Guan, 2005).

Table 1 shows the large gaps in socio-economic characteristics between Malays and Chinese in 1970 and the relative convergence by 1991, using the respective waves of the Malaysian Census. In 1970, only 5.6 percent of working-age Malays (ages 15-54) had completed secondary education, compared with 10.8 percent of Chinese. Similarly, 4.6 percent of workingage Malays were employed in high-skilled occupations, ${ }^{4}$ versus 8.7 percent of working-age Chinese.

By 1990, however, these inter-ethnic differences had either been significantly reduced or eliminated, and for education, they were reversed. The secondary-school completion rate in 1990 was 38.8 percent for Malays and 29.0 percent for Chinese. Among working-age Malays, the rate of employment in high-skilled occupations increased to 11.9 percent (a 158-percent increase), compared with 15.7 for Chinese (an 80-percent increase).

\subsection{Chinese zodiac calendar}

The Chinese astrological system ascribes personal characteristics and destinies a person's date of birth. Among its best-known aspects is the zodiac years, by which a person's birth

\footnotetext{
${ }^{4}$ High-skill occupations are managers, professionals, technicians, and associate professionals, as defined by Major Groups 1 to 3 of the International Standard Classification of Occupations 1988.
} 
year is associated with an animal; these rotate on a 12-year lunar calendar cycle. Dragon years $(1964,1976,1988,2000,2012$, etc.) are considered to be particularly auspicious years in which to be born (Goodkind, 1991).

Researchers have documented large fertility shocks during dragon years across the Chinese diaspora, beginning in the mid-1970s (see Goodkind $(1991,1993,1995)){ }^{5}$ Figure 1 plots the annual birth rates in Malaysia by ethnicity between 1970 and 1990 and covers nearly two full cycles of the Chinese zodiac calendar. Chinese birth rates spiked in 1976 and 1988, in line with the Chinese zodiac year of the dragon. During the two dragon years, Chinese birth rates increased by 10.6 and 21.7 percent, respectively, relative to the birth rates in the previous year.

These Chinese birth patterns have not escaped the notice of the public. Numerous media reports highlight shocks to birth rates during dragon years, and, anecdotally, these shocks are believed to put additional constraints on resources. For instance, the Malaysian newspaper The Star published an article in January 2012 (the start of the dragon year), in which a student recalled that "school had to increase class size for the 1988 dragon baby boom," and relatives of children born in 1988 remembered "many hospitals being fully booked that year" (Lee, 2012). Similarly, Goodkind (1991) cites Taiwanese newspaper articles prior to the 1988 dragon year that claimed that the 1976 boom led to higher maternal mortality due to increased pressure on health services and that the 1976 cohort faced overcrowded classrooms as a result of the boom.

\section{Data}

Our data come from multiple sources. We hand-enter and compile district-level birth and infant mortality records from the Peninsular Malaysian Vital Statistics. The Vital Statistics volumes provide information on the total number of live births, stillbirths, and infant deaths by district, year, and ethnicity, as well as by state, month, and ethnicity from 1970-1990. ${ }^{6}$

\footnotetext{
${ }^{5}$ Prior to 2000 , birth shocks associated with the Chinese zodiac calendar had not been noted in mainland China, due, at least in part, to the one-child policy implemented throughout most of this period (from 1979 onward) (Goodkind, 1991).

${ }^{6}$ We exclude the states of Sabah, Sarawak, and the federal territory of Labuan, all in East Malaysia. The Vital Statistics records for East Malaysia were reported separately, and our data are incomplete. Peninsular Malaysia includes 80 percent of the population of Malaysia. Moreover, East Malaysia is located more than $600 \mathrm{~km}$ away from the Malay Peninsula on the island of Borneo, is sparsely populated, and has a very different
} 
We focus on this period for two reasons. First, previous research finds no evidence of zodiac-based fertility decisions prior to 1970 in the Chinese diaspora, in part due to limited access to contraception (Sun et al., 1978; Goodkind, 1993, 1995). Second, district-level birth records by ethnicity are not available after 1990. We calculate birth rates by dividing the total number of births by the estimated population of each district-by-year-by-ethnicity cell, calculated by linearly interpolating district populations using the integrated public-use microdata samples (IPUMS) of the 1970, 1980, and 1991 Malaysian Censuses (Minnesota Population Center, 2015). ${ }^{7}$

Table 2 presents peninsular-level means from the Vital Statistics in Column 1, and Columns 2 and 3 shows these means separately for Malay and Chinese ethnic groups, respectively. Between 1970 and 1990, the average birth rate among Malays was 35.2 births per thousand, about 25 percent higher than the average Chinese birth rate of 26.9. Malay newborns made up 62.0 percent of the birth cohort each year, on average, while 27.8 percent of newborns were Chinese. The stillbirth and infant-death rates were also higher for Malays compared to Chinese. The under-1 mortality rate (the sum of stillbirth and infant-death rates) was 45.9 deaths per thousand live births for Malays and 25.4 deaths per thousand live births for Chinese.

We obtain regional data on ethnic heterogeneity, resources, and public expenditures from several sources. We use the 1970 Census to construct district-level measures of Chinese concentration, average household wealth, the fraction of households using modern fuel for cooking, per-capita teachers, per-capita health workers, and the fraction of working-age individuals employed in modern sectors. The state-level total social development expenditure between 1976-1985, which includes all NEP-related education and health programs during this period, is obtained from the Mid-Term Reviews of the Third and Fourth Malaysia Plans (Government of Malaysia, 1979, 1984). Appendix Table A.2 contains the definition of each measure and its source. Figure 2 shows the regional distribution of these measures.

Figure 2a presents the spatial distribution of the Chinese population in Malaysia. The

demographic structure compared to the rest of Malaysia, as more than half of its residents are members of one of several small indigenous tribes (non-Malay bumiputera.)

${ }^{7}$ The boundaries of some districts have changed over this period, mostly due to districts splitting into two or more districts. We merge districts that have split during the 1970-1990 period to create a set of adjusted districts that are constant over time, so that the adjusted districts closely match the district boundaries in 1970. See Appendix Table A.1 for a detailed description of which districts were merged. 
median district in Malaysia is 31 percent Chinese (restricting only to Chinese and Malays, range: $0.8,80$ ), and in 16 out of 64 districts, Chinese residents outnumber Malay residents (we refer to these as "Chinese-majority" districts). Figure $2 \mathrm{~b}$ shows district-level variation in the resource index, which we calculate by normalizing an equally-weighted mean of the standardized distributions of four resource measures: household wealth, use of modern fuel, teachers per capita, and health workers per capita. The spatial correlation between Chinese concentration and the resource index is positive and large (0.67).

Figures $2 \mathrm{c}$ and $2 \mathrm{~d}$ show the state-level variation in social development expenditure and the district-level intensity of modern sector employment, respectively. In Figure 2d, districts such as Kinta and Kuantan, which are historically productive tin mining districts in northeast and central Malaysia, show the highest intensity of modern sector jobs in 1970 (53 and 47 percent, respectively) and are therefore likely to benefit in later years from the NEP's focus on modern-sector expansion.

\section{Empirical Strategy}

We estimate the following equation as our baseline specification:

$$
\begin{aligned}
& \ln \left(\text { birthrate }_{e, d y}\right)=\alpha+\beta \text { DragonYear }_{y}+\delta \text { DragonYear }_{y} * \text { Chinese }_{e}+\gamma \text { Chinese }_{e} \\
& +\theta_{1} \text { Year } 7081_{y}+\theta_{2} Y e a r 8290_{y}+f_{d}+\epsilon_{e, d y},
\end{aligned}
$$

where the outcome variable is the log of birth rate measured at the ethnicity $(e)$-district $(d)$ year $(y)$ level. $^{8}$ DragonYear is a binary variable equal to one in 1976 and 1988. Chinese is a binary variable equal to one for Chinese-ethnicity cells. All specifications include linear year trends (one for 1970-1981 and one for 1982-1990) and district-level fixed effects $\left(f_{d}\right) .^{9}$

Our estimated coefficients of interest are $\hat{\beta}$, the differential change in log birth rates in dragon years among Malays, and $\hat{\delta}$, the differential change in log birth rates in dragon years among Chinese relative to the change among Malays. The sum of the coefficients $\hat{\beta}+\hat{\delta}$ estimates the differential change in log birth rates in dragon years for the Chinese. We

\footnotetext{
${ }^{8}$ We add one to all cells to avoid taking the log of zero.

${ }^{9}$ We also add an indicator for post-1981 births to account for a change in definition from place of occurrence to place of residence.
} 
cluster our standard errors at the district level to allow for arbitrary correlations between years within districts.

We add increased flexibility to our model by including additional controls in the baseline specification. First, we allow fertility patterns to evolve differently for Malay and Chinese ethnic groups by adding ethnicity-specific year trends. Secondly, we include ethnicity-bydistrict fixed effects and ethnicity-by-district year trends to control for ethnicity-specific fertility trends separately by district.

The main threat to the empirical strategy is that idiosyncratic calendar-year shocks could be correlated with the two dragon years and bias our estimates. To address this concern, we exploit the difference between the calendar year and the Chinese zodiac year. The 1976 dragon year started on 31 January, 1976, and ended on 17 February, 1977, while the 1988 dragon year spanned 17 February, 1988, to 5 February, 1989. We use the state-monthethnicity level data and estimate the following equation:

$$
\begin{aligned}
\ln \left(\text { birthrate }_{e, s y m}\right) & =\alpha+\beta \text { DragonYear }_{y m}+\text { SDragonYear }_{y m} * \text { Chinese }_{e}+\gamma \text { Chinese }_{e} \\
& +\sum_{i=1}^{S} \theta_{1, s} \text { Year } 7081_{y}+\sum_{i=1}^{S} \theta_{2, s} \text { Year } 8290_{y} \\
& +\sum_{i=1}^{S} \theta_{3, s} \text { Chinese } * \text { Year } 7081_{y}+\sum_{i=1}^{S} \theta_{4, s} \text { Chinese } * \text { Year } 8290_{y} \\
& +f_{e, s}+g_{e, m}+h_{e, y}+j_{s m}+k_{s y}+\epsilon_{e, s y m}
\end{aligned}
$$

where the DragonYear is a binary variable equal to one for months from February 1976 through January 1978, and months from March 1988 through January 1989. In addition to ethnicity-by-state fixed effects $\left(f_{e, s}\right)$, all specifications include ethnicity-by-month fixed effects $\left(g_{e, m}\right)$ and state-by-month fixed effects $\left(j_{s m}\right)$ to control for any region- or ethnicityspecific seasonality of birth. More importantly, we can now include ethnicity-by-year $\left(h_{e, y}\right)$ and state-by-year fixed effects $\left(k_{s y}\right)$. We also include state-ethnicity time trends in our base specification, and our most flexible specification includes ethnicity-by-state-by-year fixed effects. 


\section{Results}

\subsection{Estimation of inter-ethnic fertility spillovers}

We estimate equation 1 in order to quantify the dragon year fertility response among both Chinese and Malay ethnic groups in Columns 1 through 3 of Table 3. The results in Column 1 suggest that Chinese birth rates rose by 11.6 percent (summing 0.130 and -0.014) in dragon years. The p-value of the F-test shows that the effect on Chinese fertility is statistically significant at the one-percent level. The results are also robust to controlling for ethnicityspecific fertility trends (Column 2) and ethnicity-by-district-specific fertility trends (Column 3). In our most flexible specification (Column 3), we find that the Chinese birth rates increased by 12.7 percent in dragon years. Based on the counterfactual birth rate predicted from all 1970-1991 years excluding dragon years, this implies that the two dragon years led to approximately 26,000 additional Chinese births. ${ }^{10}$

Table 3 also shows the effect of dragon years on Malay fertility. In contrast to the Chinese, Malays reduced their birth rates by 2.0 percent during dragon years (Column 3). This implies that there were around 8,000 fewer Malay newborns in the 1976 and 1988 dragon years combined, compared to the predicted counterfactual Malay births, and this difference is statistically significant at the 1-percent level. In other words, for each additional Chinese newborn, Malays reduced their fertility by 0.30 births, suggesting the presence of large, negative, inter-ethnic fertility spillovers in Malaysia.

We can, in fact, estimate the inter-ethnic fertility spillover elasticity between Malay and Chinese ethnic groups using an instrumental variables model, assuming that Chinese beliefs about the zodiac calendar do not directly affect Malay fertility patterns. The second stage of the IV estimates the impact of Chinese birth rates on Malay birth rates, where the former variable is instrumented using the dragon-year dummy in the first stage. Not surprisingly, the dragon-year dummy is a strong predictor of Chinese births, and the results from the first-stage regression are presented in Appendix Table A.3, Column 5. The F-statistic on

\footnotetext{
${ }^{10}$ For comparison, Goodkind (1995) finds a 23-percent increase in births between 1987 and 1988. Our estimates are slightly lower because we pool the 1976 and 1988 dragon years, for which we find an 8.1 and a 17.3 percent increase among Chinese, respectively, and we control for district-by-ethnicity-specific time trends. In addition, we do not find evidence of gender differences in Chinese newborns in dragon years (see Appendix Table A.3). This is not surprising given that dragon years are thought to be auspicious for both girls and boys (for example, see Chia (1952)).
} 
the first-stage regression is 150.6. Column 4 of Table 4 show the second-stage IV estimate, which suggests that the elasticity of Malay birth rates relative to Chinese birth rates is -0.15 . The estimate is statistically significant at the one-percent level.

The Chinese birth-rate spikes and accompanying negative inter-ethnic fertility spillovers onto Malays affect dragon cohorts in two ways: by changing the overall cohort size and by shifting the relative ethnic composition. Columns 4 and 5 of Table 3 quantify these cohort size and composition effects, respectively. We find that, overall, there is around a 2.5-percent increase in birth rates, which implies a net increase of 18,000 newborns in dragon cohorts. The dragon cohort also has a Chinese concentration that is 2.6 percentage points higher, an 8.4 percent change in ethnic composition relative to the mean Chinese share (31 percent). Both estimates are statistically significant at the one-percent level.

\subsection{Robustness checks}

Our results show a positive fertility spike among Chinese and a negative response among Malays in dragon years. However, these estimates could be confounded by ethnicity-specific calendar-year shocks that are spuriously correlated with the Chinese lunar calendar. We test the robustness of our results in three different ways.

First, we use state-by-month fertility data to estimate equation 2. Since the Chinese lunar year is not perfectly correlated with the calendar year, it allows us to include calendaryear fixed effects and estimate the dragon-year effects by comparing dragon and non-dragon months within the same calendar year. We report these results in Columns 1 and 2 of Table 4. The results in Column 2, which includes ethnicity-by-state-by-year fixed effects, confirm that there was a large, statistically significant fertility response among both the Chinese and Malay populations. Chinese birth rates increased by 11.4 percent, and Malay birth rates declined by 0.7 percent in dragon years. The two estimates are statistically significant at the one-percent and five-percent levels, respectively. ${ }^{11}$

\footnotetext{
${ }^{11}$ Because we achieve identification based on the margins of the lunar year, potential imprecision in the effectiveness of conception timing makes it likely that we underestimate the magnitude of the negative Malay response. Indeed, we see that the coefficient in Table 4 (-0.7 percent) is roughly half of the -1.9percent estimate in Table 3. This difference could also reflect heterogeneous responses across the lunar year. For example, if the Chinese response is bell-shaped to minimize the chance of "missing" the dragon year, Malay responses may also be inversely bell-shaped if families sought to avoid giving birth during peak times.
} 
Second, we estimate the fertility responses from Malay and Chinese ethnic groups in tiger years (1974 and 1986) alongside with their responses in dragon years. According to the Chinese zodiac calendar, the tiger year is considered an inauspicious year for birth, particularly for girls (Goodkind, 1991). Therefore, we hypothesize a reduction in Chinese births and a corresponding rise in Malay births. Column 3 of Table 4 includes a tiger-year and tiger-year-by-ethnicity fixed effect. Indeed, we see that Chinese birth rates declined by 2.3 percent and Malays birth rates increased by 3.3 percent, and both estimates are statistically significant at the 1-percent level.

Lastly, we allow the fertility response to vary between Chinese-majority and non-majority districts. Given that an increase in Chinese birth rates leads to relatively larger Chinese cohorts in high-Chinese concentration areas, we should therefore expect that these areas would have more negative Malay fertility responses. In line with our prior, Malay fertility declined by 2.8 percent in Chinese-majority districts and by 1.6 percent in non-majority districts (Column 4). This regional difference in Malay response is large (almost double in magnitude), though it is not statistically significant at conventional levels.

\subsection{Evidence of forward-looking behavior}

The changes in composition and cohort size induced by dragon years is likely to affect the lifetime expected return to childbearing by putting additional strain on public resources, such as hospitals and schools. In this section, we provide three pieces of evidence that the negative inter-ethnic fertility spillovers we observe are in part due to the differences in the net returns of childbearing, particularly through access to resources. This forward-looking behavior on the part of Malays may reflect immediate future costs, such as childbirth and post-natal care, as well as more long-run costs, such as access to schools and labor-market competition. We continue to restrict our focus to Malays because their responses are not confounded by potential differences in beliefs surrounding the zodiac calendar across regions or family characteristics.

Differential fertility responses by relative resources: We estimate the Malay fertility response separately by districts with different levels of resources. We anticipate that the returns to childbearing will be most adversely affected in areas with relatively lower 
resource levels ex ante. In Table 5, we use four district-level measures to proxy for the availability of resources, all measured as of 1970: an average household wealth index, the share of households using modern cooking fuels for heating and cooking, the number of teachers per capita, and the number of health workers per capita.

The results in Columns 1 through 4 of Table 5 show that, indeed, increased districtlevel resources mitigate the negative Malay fertility response to increased Chinese births in dragon years. In districts with below-median resources, there is a consistently more negative fertility response among Malays across all four resource measures. Because there is a relatively high, positive correlation between these four measures, in Column 5 we use a district-level resource index constructed by normalizing an equally-weighted mean of the standardized distributions of four resource measures. The Malay fertility response in lowresource districts is -3.1 percent, while in high-resource districts it is only - 0.6 percent (and not statistically significant). The former is statistically significant at the one-percent level. The Malay fertility response to Chinese births in a low-resource district is more than five-fold larger in magnitude relative the response in a high-resource district, and this difference is also statistically significant at the one-percent level.

Additionally, after accounting for access to resources, the negative impact of Chinese concentration on Malay birth rates during dragon years is still negative, but it is much larger in magnitude than previously estimated in Table 4, reflecting the positive correlation between the population share of Chinese and access to resources. In Chinese majoritydistricts, Malays reduced birth rates by an additional 1.9 percent (significant at the 10percent level), holding constant all other factors.

Differential fertility responses by public expenditures: Second, the state may affect the net returns to childbearing by its investment in public resources or through ethnicityspecific policies, especially if fertility decisions are influenced by inter-ethnic competition for resources. This issue is particularly relevant in Malaysia because the government implemented a series of economic policies under the NEP to protect its Malay population and reduce competition with other ethnic groups, particularly the Chinese. For this purpose, we estimate the Malay fertility response to additional Chinese births in dragon years differentially by regions with different degrees of separation.

We consider one indirect and one direct measure of state investments during the NEP 
period: (1) the 1970 share of the employment in "modern sectors," as described explicitly in the Third Malaysia Plan and (2) the log of per-capita total spending in social development programs, which include education and training, health and family planning, and social and community services (Government of Malaysia, 1976). This spending makes up approximately 31 percent of federal development expenditures across each Malaysia Plan. Because funding decisions for development programs and NEP activity were made jointly by the federal government, we cannot isolate development programs from NEP activity, but we can examine their impact together as part of the state's attempts to address resource competition.

Table 6 reports the results of interacting these two measures separately with dragon-year and dragon-year-by-Chinese indicators. For reference, Column 1 repeats Column 5 of Table 5. Column 2 shows that, as the share of employment in the modern sector increases, the Malay response in dragon years is mitigated. This differential response partly, though not entirely, captures some of the relationship between fertility decisions and access to resources, as the coefficient on the dragon-year-by-resource-index interaction term falls and is no longer statistically significant. In Column 3, we find that a greater investment in social development programs also lessens the negative Malay fertility response above and beyond the effect of resources on Malay fertility. The coefficient on the interaction term (dragon year-by-social expenditure) is positive and statistically significant at the 10-percent level. Taken together, these results emphasize the role of state policies in mitigating Malay responses to Chinese fertility decisions by improving resources in general or for Malays.

Decline in infant health outcomes among the dragon cohort: Lastly, we provide direct evidence of worse infant health outcomes among the dragon cohort, which suggests that increased Chinese births may, indeed, have put pressure on hospital resources and made access to quality medical care more difficult for Malays. In line with the existing literature that documents an adverse effect of negative income shock on infant mortality (Bhalotra, 2010; Baird et al., 2011), we consider whether dragon years bring increased risk of stillbirth or infant mortality (before age one) for children born at that time.

Columns 1, 2, and 3 of Table 7 report the results of flexibly estimating equation 1, replacing the dependent variable with the $\log$ stillbirth rate, log infant-death rate, and the $\log$ of the pooled stillbirth and infant-death rate (labeled "under-1 mortality rate"), respectively. Overall, Malay dragon-year births are associated with worse health outcomes. 
In dragon years, the Malay stillbirth, infant death, and under-1 mortality rates increased by $3.3,2.3$, and 2.4 percent respectively, and the latter two estimates are statistically significant at the 10-percent level. For Chinese, on the other hand, we find slightly a lower risk of infant death and under-1 mortality, though these results are not statistically significant at conventional levels.

The rise in mortality rates for Malays born in dragon years is consistent with an increased strain on medical resources during dragon years. However, this mechanism may be confounded by selection into childbearing. The differential cost of having children in dragon years may vary based on individual and household characteristics within the Malay population, as well as based on their ability to respond to these perceived changes. Similarly, Chinese children born in auspicious years may benefit relative to Chinese children born in other years because they are better planned by their parents (Do and Phung, 2010) or because their families, who respond to the lunar calendar, are positively selected (Johnson and Nye, 2011).

We use 1991 Census data to predict the characteristics of families that have children during dragon years relative to those who have children in non-dragon years. ${ }^{12}$ We consider household characteristics such as family composition and household wealth, as well as parents' characteristics such as education and employment. We find no evidence that Malay families who have children in dragon years are negatively selected, and therefore the negative health outcomes we observe in Table 7 are unlikely to be driven by selection (see Appendix Table A.8).

\section{Conclusion}

In this paper, we exploit variation in the Chinese lunar calendar to document inter-ethnicity fertility spillovers in Peninsular Malaysia. We find that in auspicious dragon years, Chinese births rise by 12.7 percent (26,000 additional births across both cycles), and Malays respond by reducing their births by 2.0 percent $(8,000$ fewer births across both cycles). Our results are highly robust to alternative specifications, and we document a similar, but reverse

\footnotetext{
${ }^{12}$ Appendix Table A.6 demonstrates that we also detect large and statistically significant dragon-year fertility responses among both Chinese and Malays in the 1991 Census.
} 
phenomenon in inauspicious tiger years.

The change in cohort size and ethnic composition induced by dragon years may drive inter-ethnic spillovers through several mechanisms. Malays may prefer not to have children in Chinese "boom" years, they may seek to avoid increased costs of childbearing, or they may seek to avoid anticipated long-run disadvantages for their children as a result of increased competition within their cohort for resources. We present strong suggestive evidence that an important factor driving Malay fertility responses is forward-looking fertility-timing behavior among families seeking to maximize the net returns to childbearing.

Specifically, we observe fertility spillovers among Malays are particularly negative in areas with scarcer public resources, where the strain of cohort size is greatest. Additionally, government investment also affects the intensity of the spillover. Areas with increased government investment experience smaller negative fertility spillovers among Malays. Finally, consistent with larger birth cohorts putting increased pressure on resources, we observe higher stillbirth and infant mortality rates among Malays in dragon years, and we do not find that this difference can be explained by negative selection into childbearing.

These results demonstrate that individuals display forward-looking behavior in their conception timing, complementing work on the impact of changes in the net returns to childbearing on overall fertility (Lovenheim and Mumford, 2013; Apostolova-Mihaylova and Yelowitz, 2016) and fertility timing decisions (Dickert-Conlin and Chandra, 1999; Gans and Leigh, 2009; Turner, 2014). Additionally, these results highlight the role of individual behavior in mitigating inter-ethnic tensions brought on by resource competition, as well as the ability of government investment to influence this competition directly, through the provision of additional resources or redistribution of resources. 


\section{References}

Alesina, Alberto and Eliana La Ferrara, "Ethnic Diversity and Economic Performance," Journal of Economic Literature, 2005, 43 (3), 762-800.

_ , Reza Baqir, and William Easterly, "Public Goods and Ethnic Divisions," Quarterly Journal of Economics, 1999, pp. 1243-1284.

Apostolova-Mihaylova and Aaron Yelowitz, "Health Insurance, Fertility, and the Wantedness of Pregnancies: Evidence from Massachusetts," 2016.

Artadi, Elsa V., "Going into Labor: Earnings vs. Infant Survival in Rural Africa," Mimeograph, Bocconi University, 2005.

Baird, Sarah, Jed Friedman, and Norbert Schady, "Aggregate Income Shocks and Infant Mortality in the Developing World," Review of Economics and Statistics, 2011, 93 (3), 847-856.

Banerjee, Abhijit, Lakshmi Iyer, and Rohini Somanathan, "History, Social Divisions, and Public Goods in Rural India," Journal of the European Economic Association, 2005, 3 (2-3), 639-647.

Baum-Snow, Nathaniel and Byron F. Lutz, "School Desegregation, School Choice, and Changes in Residential Location Patterns by Race," American Economic Review, 2011, 101 (7), 3019-3046.

Becker, Gary S., A Treatise on the Family, enl. ed, Harvard University Press, 1991.

- and H. Gregg Lewis, "On the Interaction between the Quantity and Quality of Children," Journal of Political Economy, 1973, 81 (2), S279-S288.

Besley, Timothy, Rohini Pande, and Vijayendra Rao, "Just Rewards? Local Politics and Public Resource Allocation in South India," World Bank Economic Review, 2012, 26 (2), 191-216.

Bhalotra, Sonia, "Fatal Fluctuations? Cyclicality in Infant Mortality in India," Journal of Development Economics, 2010, 93 (1), 7-19.

Blythe, W. L., "Historical Sketch of Chinese Labour in Malaya," Journal of the Malayan Branch of the Royal Asiatic Society, 1947, 20 (1), 64-114.

Boeri, Tito, Marta De Philippis, Eleonora Patacchini, and Michele Pellizzari, "Immigration, Housing Discrimination and Employment," Economic Journal, 2015, 125 (586), F82-F114.

Bound, John and Sarah Turner, "Cohort Crowding: How Resources Affect Collegiate Attainment," Journal of Public Economics, 2007, 91 (5), 877-899.

Brunner, Eric J., Jennifer Imazeki, and Stephen L. Ross, "Universal Vouchers and Racial and Ethnic Segregation," Review of Economics and Statistics, 2010, 92 (4), 912927.

Card, David, Alexandre Mas, and Jesse Rothstein, "Tipping and the Dynamics of Segregation," Quarterly Journal of Economics, 2008, pp. 177-218. 
- and Jesse Rothstein, "Racial Segregation and the Black-White Test Score Gap," Journal of Public Economics, 2007, 91 (11), 2158-2184.

Chevalier, Arnaud and Olivier Marie, "Economic Uncertainty, Parental Selection, and Children's Educational Outcome," Journal of Political Economy, forthcoming.

Chia, K. S., "Marry a 'Dragon' and You Can’t Go Wrong," 3 Feb 1952.

Deming, David and Susan Dynarski, "The Lengthening of Childhood," Journal of Economic Perspectives, 2008, 22 (3), 71-92.

Department of Statistics, "1957 Population Census of the Federation of Malaya, Report No. 14: Final Report, Summary Tables for the Federation with General Comments on the Census," 1958.

_ , "Household Budget Survey of the Federation of Malaya 1957-58," 1959.

_ , "Population Distribution and Basic Demographic Characteristic Report 2010," 2015. Last accessed: 02 November 2016.

Dickert-Conlin, Stacy and Amitabh Chandra, "Taxes and the Timing of Births," Journal of Political Economy, 1999, 107 (1), 161-177.

Do, Quy-Toan and Tung D. Phung, "The Importance of Being Wanted," American Economic Journal: Applied Economics, 2010, 2 (4), 236-253.

Douglas, Almond Jr., Kenneth Chay, and Michael Greenstone, "Civil Rights, the War on Poverty, and Black-White Convergence in Infant Mortality in the Rural South and Mississippi," American Economic Review, forthcoming.

Easterly, William and Ross Levine, "Africa's Growth Tragedy: Policies and Ethnic Divisions," Quarterly Journal of Economics, 1997, pp. 1203-1250.

Esteban, Joan and Debraj Ray, "A Model of Ethnic Conflict," Journal of the European Economic Association, 2011, 9 (3), 496-521.

_ , Laura Mayoral, and Debraj Ray, "Ethnicity and Conflict: An Empirical Study," American Economic Review, 2012, 102 (4), 1310-1342.

Faaland, Just, John Richard Parkinson, and Rais Saniman, Growth and Ethnic Inequality: Malaysia's New Economic Policy, Utusan Publications \& Distributors, 2003.

Fairlie, Robert W. and Alexandra M. Resch, "Is There "White Flight" into Private Schools? Evidence from the National Educational Longitudinal Survey," Review of Economics and Statistics, 2002, 84 (1), 21-33.

Gans, Joshua S. and Andrew Leigh, "Born on the First of July: An (un)Natural Experiment in Birth Timing," Journal of Public Economics, 2009, 93 (1), 246-263.

Goodkind, Daniel M., "Creating New Traditions in Modern Chinese Populations: Aiming for Birth in the Year of the Dragon," Population and Development Review, 1991, pp. 663686.

_ , "New Zodiacal Influences on Chinese Family Formation: Taiwan, 1976," Demography, 1993, 30 (2), 127-142. 
_, "The Significance of Demographic Triviality: Minority Status and Zodiacal Fertility Timing among Chinese Malaysians," Population Studies, 1995, 49 (1), 45-55.

Government of Malaysia, "The Second Malaysia Plan, 1971-1975," 1971.

_ , "The Third Malaysia Plan, 1976-1980," 1976.

_ , "Mid-Term Review of the Third Malaysia Plan, 1976-1980," 1979.

_, "Mid-Term Review of the Fourth Malaysia Plan, 1981-1985," 1984.

Guan, Lee Hock, "Affirmative action in Malaysia," Southeast Asian Affairs, 2005, pp. 211228.

Gupta, Monica Das, "Selective Discrimination Against Female Children in Rural Punjab, India," Population and Development Review, 1987, pp. 77-100.

Hirschman, Charles, "Data Documentation and Codebooks of the Merged (Pooled) Files of the 1970 and 1980 Census Microdata Samples," undated. Last accessed: 04 November 2016.

Hsieh, Chang-Tai, Erik Hurst, Charles I. Jones, and Peter J. Klenow, "The Allocation of Talent and US Economic Growth," Technical Report, National Bureau of Economic Research 2013.

i Miquel, Gerard Padró, "The Control of Politicians in Divided Societies: The Politics of Fear," Review of Economic Studies, 2007, 74 (4), 1259-1274.

Johnson, Noel D. and John V.C. Nye, "Does Fortune Favor Dragons?," Journal of Economic Behavior 83 Organization, 2011, 78 (1), 85-97.

Karimova, Alfia, "Learning Through Experience: Evidence from Prenatal Ramadan Exposure," 2015.

Kerr, William R. and Martin Mandorff, "Social Networks, Ethnicity, and Entrepreneurship," Technical Report, National Bureau of Economic Research 2015.

Kureishi, Wataru and Midori Wakabayashi, "Taxing the Stork," National Tax Journal, 2008, pp. 167-187.

Lau, Yan, "The Dragon Cohort of Hong Kong: Superstitions, Demographics and Education," 2015.

Lee, Jungmin and Myungho Paik, "Sex Preferences and Fertility in South Korea during the Year of the Horse," Demography, 2006, 43 (2), 269-292.

Lee, Yen Mun, "No Silver Platter for Gen Y Babies," 2012.

Lichtman-Sadot, Shirlee, "The Value of Postponing Pregnancy: California's Paid Family Leave and the Timing of Pregnancies," The BE Journal of Economic Analysis \& Policy, 2014, 14 (4).

Lovenheim, Michael F. and Kevin J. Mumford, "Do Family Wealth Shocks Affect Fertility Choices? Evidence from the Housing Market," Review of Economics and Statistics, 2013, 95 (2), 464-475. 
Means, Gordon P, "Ethnic Preference Policies in Malaysia," Ethnic Preference and Public Policy in Developing States, 1986, pp. 95-117.

Miguel, Edward and Mary Kay Gugerty, "Ethnic Diversity, Social Sanctions, and Public Goods in Kenya," Journal of Public Economics, 2005, 89 (11), 2325-2368.

Minnesota Population Center, "Integrated Public Use Microdata Series, International: Version 6.4 [Machine-readable database]," 2015.

Montalvo, Jose G and Marta Reynal-Querol, "Ethnic Diversity and Economic Development," Journal of Development economics, 2005, 76 (2), 293-323.

Purcell, Victor, The Chinese in Malaysia, Oxford University Press, 1948.

Rahman, Momotazur and Andrew D. Foster, "Racial Segregation and Quality of Care Disparity in US Nursing Homes," Journal of Health Economics, 2015, 39, 1-16.

Reiling, Rune Borgan, "Does Size Matter? Educational Attainment and Cohort Size," Journal of Urban Economics, 2016, 94, 73-89.

Saavedra, Juan Esteban, "Resource Constraints and Educational Attainment in Developing Countries: Colombia 1945-2005," Journal of Development Economics, 2012, 99 (1), $80-91$.

Sun, Te-Hsiung, Hui-Sheng Lin, and Ronald Freedman, "Trends in Fertility, Family Size Preferences, and Family Planning Practice: Taiwan, 1961-76," Studies in Family Planning, 1978, 9 (4), 54-70.

Tiebout, Charles M, "A Pure Theory of Local Expenditures," Journal of Political Economy, 1956, pp. 416-424.

Turner, Nicholas, "New Evidence on Taxes and the Timing of Birth," American Economic Journal: Economic Policy, 2014.

Vere, James P., "Dragon Children: Identifying the Causal Effect of the First Child on Female Labour Supply with the Chinese Lunar Calendar," Oxford Bulletin of Economics and Statistics, 2008, 70 (3), 303-325.

Wong, Ken Lin, The Malaysian Tin Industry to 1914, Vol. 14, The University of Arizona Press, 1965. 


\section{$7 \quad$ Figures and Tables}

Figure 1: Annual Birth Rates by Ethnicity, 1970-1990

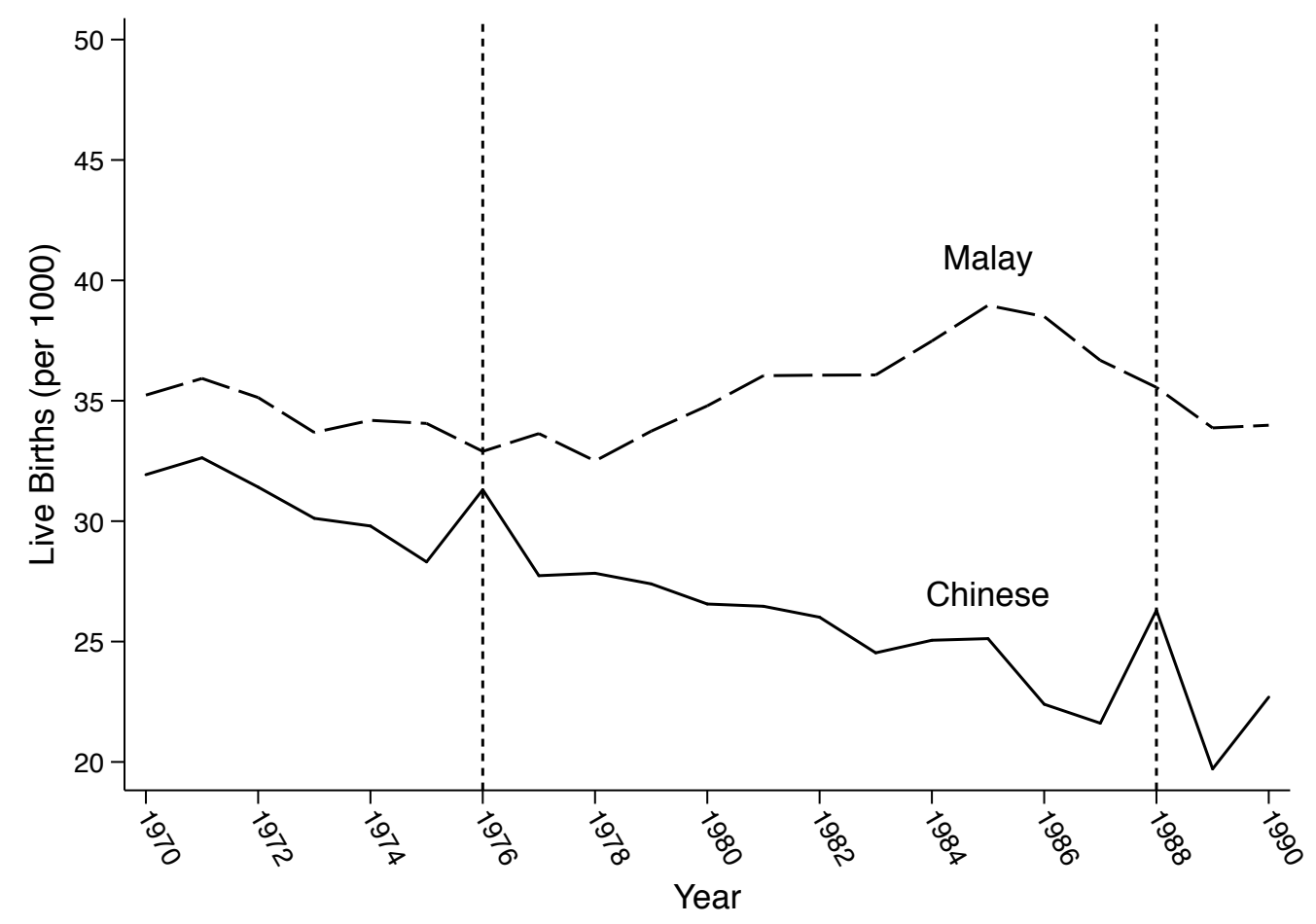

Notes: Birth rates are calculated by dividing the total number of live births by the estimated year-by-ethnicity population, calculated based on a linear interpolation of ethnicity population using the 1970, 1980, and 1991 Malaysia Censuses. Dragon years (1976 and 1988) are indicated using a dotted line. 
Figure 2: Regional Distribution of Chinese Ethnicity, Resources, and Public Expenditures

(a) Chinese Concentration, 1970



Mean: 0.327 , median: 0.317 , s.d. 0.212

Notes: Chinese concentration is the Chinese share of the population of Chinese and Malays. Source: Malaysian Census, 1970.

(c) Social Development Expenditure Per Capita, 1976-1985

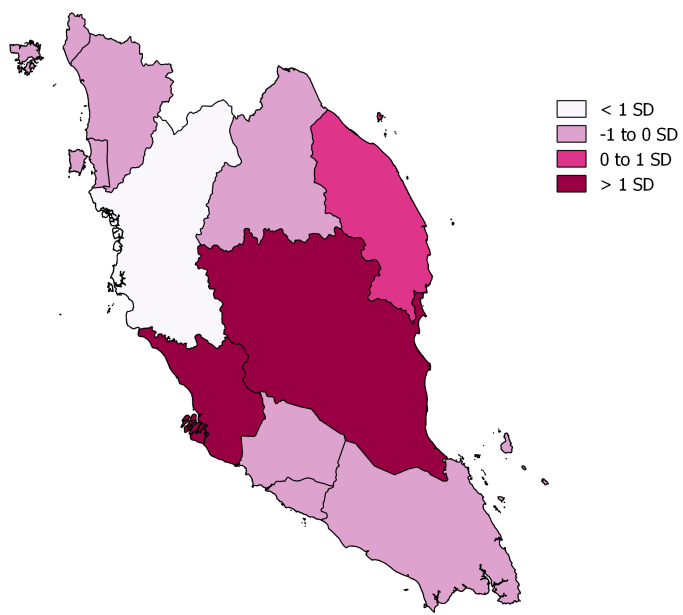

Mean: 0.878 , median: 0.762 , s.d. 0.341 .

Notes: Social development expenditures are the revised amount of federal public development expenditures allocated to states. See Appendix Table A.2 for more details. Source: Mid-Term Review of the Third Malaysia Plan, Mid-Term Review of the Fourth Malaysia Plan. (b) Resource Index, 1970

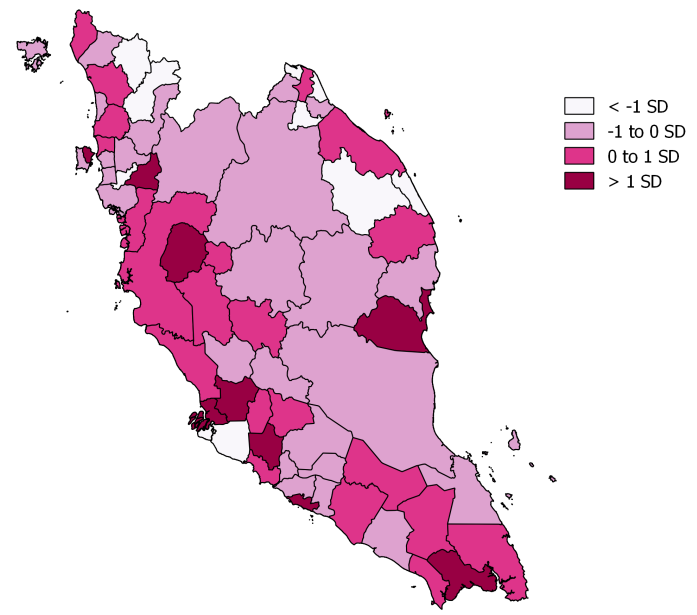

Mean: 0.000, median: -0.031, s.d. 1.000 .

Notes: The resource index is an equally-weighted sum of four standardized measures of resources. See Appendix Table A.2 for more details. Source: Malaysian Census, 1970.

(d) Modern Sector Intensity, 1970

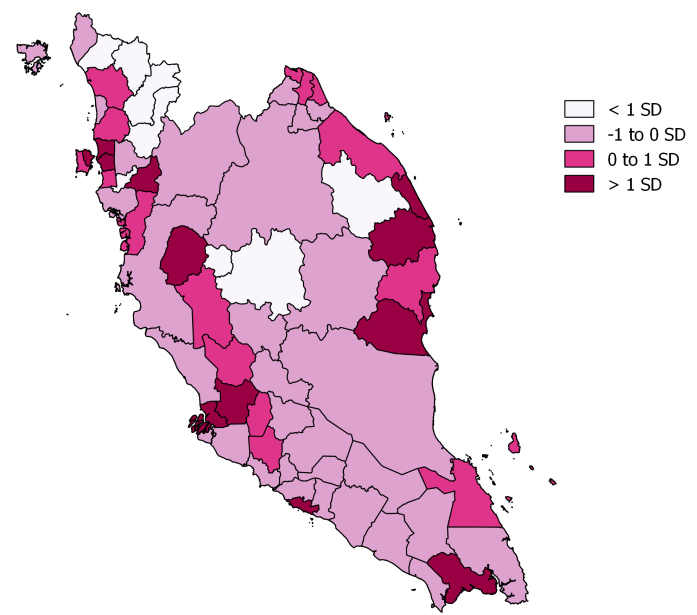

Mean: 0.185, median: 0.150, s.d. 0.115.

Notes: Modern sector intensity is the share of employed individuals working in the manufacturing, mining, construction, or commerce sector. See Appendix Table A.2 for more details. Source: Malaysian Census, 1970. 
Table 1: Characteristics of Malay and Chinese Ethnic Groups, 1970 and 1991 Censuses

\begin{tabular}{ccccccc}
\hline \hline & \multicolumn{2}{c}{ Malay } & & \multicolumn{3}{c}{ Chinese } \\
\cline { 6 - 7 } \cline { 5 - 7 } \cline { 5 - 7 } & 1970 & 1991 & & 1970 & 1991 \\
& $(1)$ & $(2)$ & & $(3)$ & $(4)$ \\
\hline
\end{tabular}

Panel A: Characteristics of population

Total population ('000) $\quad 4,681 \quad 8,119 \quad 3,126 \quad 3,962$

$\begin{array}{lllll}\text { Share of population (in \%) } & 53.2 & 58.9 & 35.5 & 28.7\end{array}$

Panel B: Characteristics of working-age group (in \%), ages 15-54

\begin{tabular}{lcccc} 
Primary education & 48.6 & 82.5 & 42.1 & 83.0 \\
Secondary education & 4.1 & 36.2 & 8.0 & 26.0 \\
Tertiary education & 0.5 & 7.0 & 1.2 & 6.5 \\
Employment rate $^{\text {Employed in high-skill occupation }}{ }^{a}$ & 56.4 & 57.8 & 57.2 & 61.2 \\
Employed in modern sector $^{b}$ & 12.6 & 11.9 & 8.7 & 15.7 \\
\hline
\end{tabular}

Panel C: Household characteristics

\begin{tabular}{lcccc} 
Urban residence (in \%) & 20.5 & 46.7 & 71.9 & 85.7 \\
Household size & 4.6 & 4.8 & 4.9 & 4.7 \\
Number of children & 2.1 & 2.0 & 2.1 & 1.4 \\
Female household head & 19.3 & 17.9 & 23.7 & 20.2 \\
Age of household head & 41.8 & 43.8 & 43.7 & 46.8 \\
Household wealth index $^{c}$ & 0.3 & 0.5 & 0.4 & 0.7 \\
Modern cooking fuel $^{d}$ (in \%) & 21.1 & - & 27.6 & - \\
\hline \hline
\end{tabular}

Notes: Sample includes Peninsular Malaysia, and it also includes non-citizens in 1970 but not in 1991. ${ }^{a}$ High-skill occupations are managers, professionals, technicians, and associate professionals, as defined by Major Groups 1 to 3 of the International Standard Classification of Occupations 1988. ${ }^{b}$ Modern sectors are manufacturing, mining, commerce, and construction, which were explicitly targeted by the NEP to increase Malay participation. ${ }^{c}$ Household wealth index is the equally-weighted mean of five indicator variables for whether the household owns any refrigerators, automobiles, phones, televisions, and radios. ${ }^{d}$ Modern cooking fuels are electricity, gas, or kerosene, as opposed to wood or charcoal. 
Table 2: Summary Statistics of Vital Statistics, 1970-1990

\begin{tabular}{|c|c|c|c|}
\hline & $\begin{array}{c}\text { National } \\
\text { (1) }\end{array}$ & $\begin{array}{l}\text { Malay } \\
(2)\end{array}$ & $\begin{array}{c}\text { Chinese } \\
(3)\end{array}$ \\
\hline Mean birth rate & 31.8 & 35.2 & 26.9 \\
\hline Mean cohort size & 350,727 & 219,302 & 96,030 \\
\hline Mean share of cohort (\%) & 100.0 & 62.0 & 27.8 \\
\hline Mean stillbirth rate (per 1000 live births) & 15 & 17.1 & 8.1 \\
\hline Mean infant death rate (per 1000 live births) & 25.3 & 28.7 & 17.3 \\
\hline Mean under-1 mortality rate (per 1000 live births) & 40.3 & 45.9 & 25.4 \\
\hline
\end{tabular}




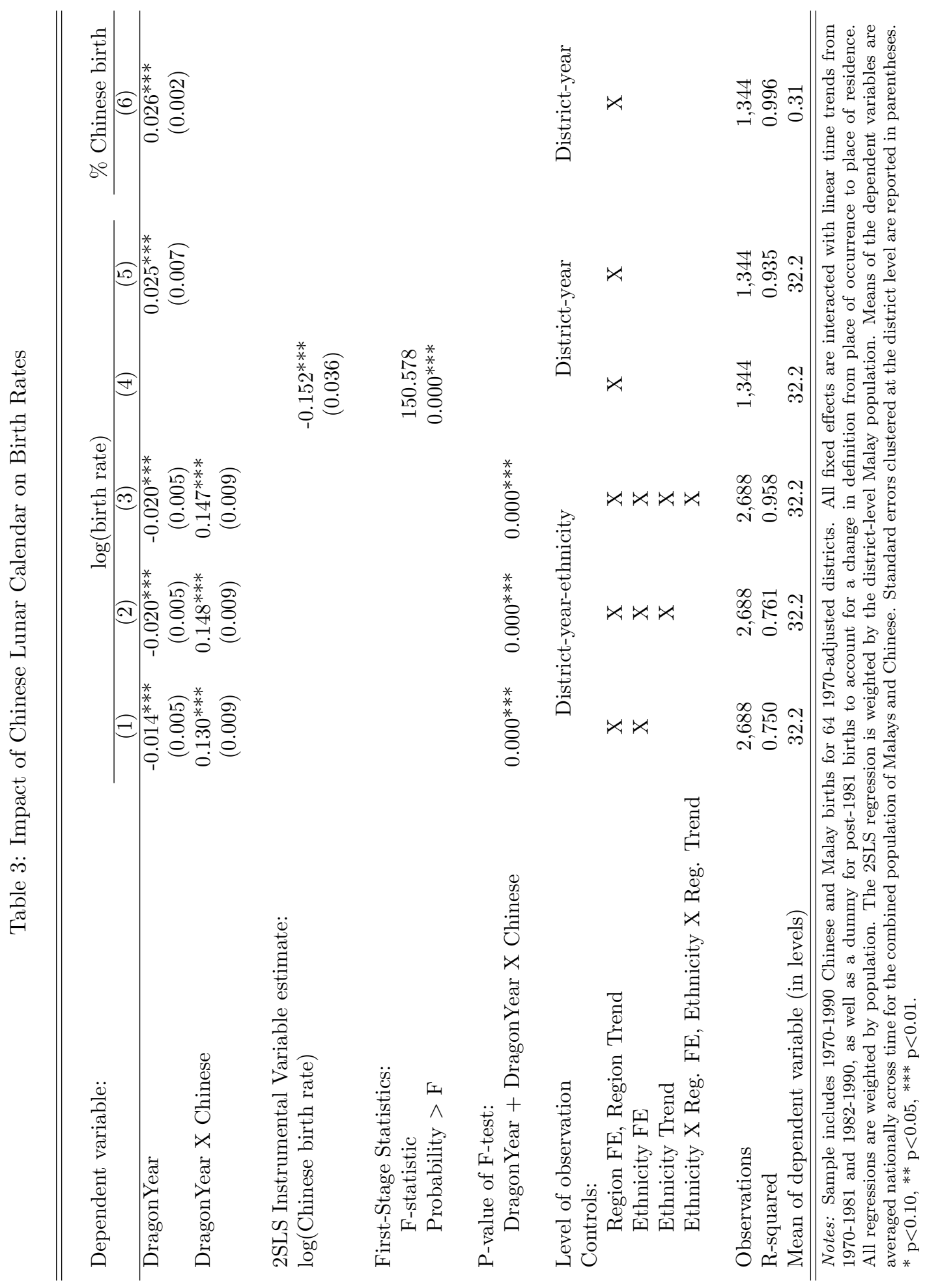


Table 4: Impact of Chinese Lunar Calendar on Birth Rates, Robustness Checks

\begin{tabular}{|c|c|c|c|c|}
\hline & $(1)$ & $(2)$ & $(3)$ & $(4)$ \\
\hline DragonYear & $\begin{array}{c}-0.007^{* *} \\
(0.003)\end{array}$ & $\begin{array}{c}-0.007^{* *} \\
(0.003)\end{array}$ & $\begin{array}{c}-0.016^{* * *} \\
(0.005)\end{array}$ & $\begin{array}{c}-0.017^{* * *} \\
(0.005)\end{array}$ \\
\hline DragonYear X Chinese & $\begin{array}{c}0.121^{* * *} \\
(0.009)\end{array}$ & $\begin{array}{c}0.121^{* * *} \\
(0.008)\end{array}$ & $\begin{array}{c}0.141^{* * *} \\
(0.009)\end{array}$ & $\begin{array}{c}0.147^{* * *} \\
(0.009)\end{array}$ \\
\hline TigerYear & & & $\begin{array}{c}0.033^{* * *} \\
(0.004)\end{array}$ & \\
\hline TigerYear X Chinese & & & $\begin{array}{c}-0.056^{* * *} \\
(0.007)\end{array}$ & \\
\hline DragonYear X Chinese majority (ChMaj) & & & & $\begin{array}{l}-0.011 \\
(0.012)\end{array}$ \\
\hline DragonYear X Chinese X ChMaj & & & & $\begin{array}{c}0.007 \\
(0.019)\end{array}$ \\
\hline \multicolumn{5}{|l|}{$\mathrm{P}$-value of F-test: } \\
\hline $\begin{array}{l}\text { DragonYear + DragonYear X Chinese } \\
\text { TigerYear + TigerYear X Chinese }\end{array}$ & $0.000^{* * *}$ & $0.000^{* * *}$ & $\begin{array}{l}0.000^{* * *} \\
0.000^{* * *}\end{array}$ & $0.000^{* * *}$ \\
\hline DragonYear + DragonYear X ChMaj & & & & $0.008^{* * *}$ \\
\hline Level of observation & \multicolumn{2}{|c|}{ State-month-ethnicity } & \multicolumn{2}{|c|}{ District-year-ethnicity } \\
\hline \multicolumn{5}{|l|}{ Controls: } \\
\hline Ethn. X Reg. FE, Ethn. X Reg. Trend & $\mathrm{X}$ & $\mathrm{X}$ & $\mathrm{X}$ & $\mathrm{X}$ \\
\hline Ethn. X Month FE, Reg. X Month FE & $\mathrm{X}$ & $\mathrm{X}$ & & \\
\hline Ethn. X Year FE, Reg. X Year FE & $\mathrm{X}$ & $\mathrm{X}$ & & \\
\hline Ethn. X Region X Year FE & & $\mathrm{X}$ & & \\
\hline Observations & 5,126 & 5,126 & 2,688 & 2,688 \\
\hline R-squared & 0.919 & 0.921 & 0.958 & 0.958 \\
\hline Mean of dependent variable (in levels) & 2.68 & 2.68 & 32.2 & 0.31 \\
\hline \multicolumn{5}{|c|}{$\begin{array}{l}\text { Notes: Dependent variable is log (birth rate). State-month-ethnicity observations start from August } 1970 \text {, the } \\
1970 \text { Census enumeration month. For Columns } 1 \text { and } 2 \text {, the dragon year dummy is assigned to months that } \\
\text { are completely within the dragon year, which are February } 1976 \text { to January } 1977 \text { and March } 1988 \text { to January } \\
1989 \text {. All specifications include fully interacted region-ethnicity fixed effects and trends, as used in Column } 3 \text { of } \\
\text { Table } 3 \text {. All regressions are weighted by population. Means of the dependent variables are averaged nationally } \\
\text { across time for the combined Malay and Chinese population. Standard errors are clustered at the district level } \\
\text { in Columns } 3-4 \text { and at the state level in Columns } 1-2 \text {, and they are reported in parentheses. Given a small } \\
\text { number of states, we also calculate the p-values using the t-asymptotic wild cluster bootstrap at the state } \\
\text { level for DragonYear and DragonYear X Chinese variables in Columns } 1-2 \text {, and the results are robust to the } \\
\text { statistical inference procedure. }{ }^{*} \mathrm{p}<0.10,{ }^{* *} \mathrm{p}<0.05,{ }^{* * *} \mathrm{p}<0.01 \text {. }\end{array}$} \\
\hline
\end{tabular}




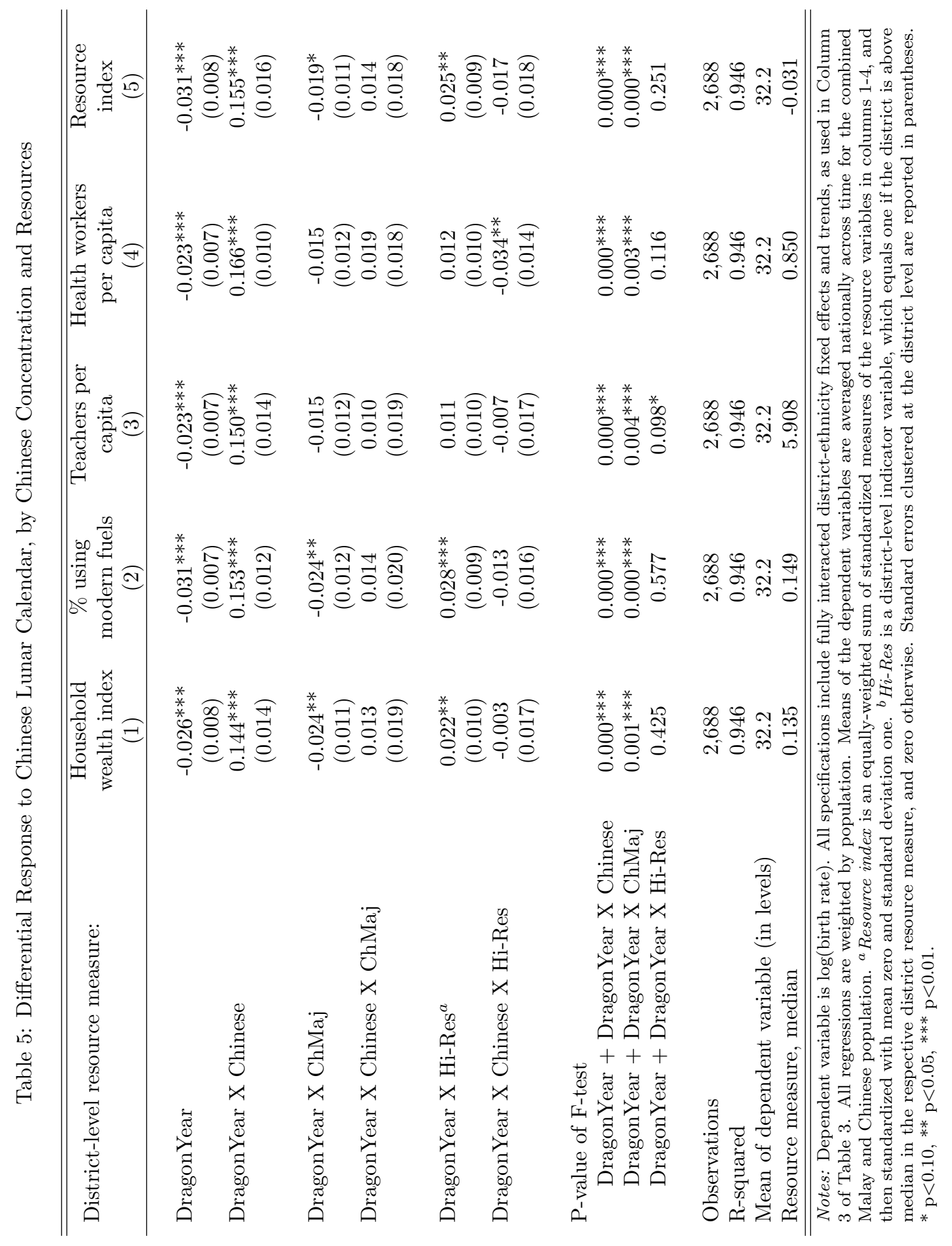


Table 6: Differential Response to Chinese Lunar Calendar, by Public Investments

\begin{tabular}{|c|c|c|c|}
\hline & $\overline{(1)}$ & $\overline{(2)}$ & $\overline{(3)}$ \\
\hline DragonYear & $\begin{array}{c}-0.031^{* * *} \\
(0.008)\end{array}$ & $\begin{array}{c}-0.041^{* * *} \\
(0.009)\end{array}$ & $\begin{array}{c}-0.024^{* * *} \\
(0.009)\end{array}$ \\
\hline DragonYear X Chinese & $\begin{array}{c}0.155^{* * *} \\
(0.016)\end{array}$ & $\begin{array}{c}0.161^{* * *} \\
(0.018)\end{array}$ & $\begin{array}{c}0.141^{* * *} \\
(0.020)\end{array}$ \\
\hline DragonYear X ChMaj & $\begin{array}{c}-0.019^{*} \\
(0.011)\end{array}$ & $\begin{array}{c}-0.032^{* *} \\
(0.015)\end{array}$ & $\begin{array}{c}-0.024^{* *} \\
(0.010)\end{array}$ \\
\hline DragonYear X Chinese X ChMaj & $\begin{array}{c}0.014 \\
(0.018)\end{array}$ & $\begin{array}{c}0.020 \\
(0.017)\end{array}$ & $\begin{array}{c}0.023 \\
(0.022)\end{array}$ \\
\hline DragonYear X Hi-Res & $\begin{array}{c}0.025^{* *} \\
(0.009)\end{array}$ & $\begin{array}{c}0.016 \\
(0.011)\end{array}$ & $\begin{array}{c}0.025^{* * *} \\
(0.009)\end{array}$ \\
\hline DragonYear X Chinese X Hi-Res & $\begin{array}{l}-0.017 \\
(0.018)\end{array}$ & $\begin{array}{c}-0.012 \\
(0.019)\end{array}$ & $\begin{array}{l}-0.019 \\
(0.016)\end{array}$ \\
\hline DragonYear X Modern sector intensity $(\text { ModSec })^{a}$ & & $\begin{array}{c}0.083 \\
(0.050)\end{array}$ & \\
\hline DragonYear X Chinese X ModSec & & $\begin{array}{l}-0.045 \\
(0.072)\end{array}$ & \\
\hline DragonYear X Social expenditure $(\operatorname{SocExp})^{b}$ & & & $\begin{array}{c}0.018^{*} \\
(0.011)\end{array}$ \\
\hline DragonYear X Chinese X SocExp & & & $\begin{array}{l}-0.035 \\
(0.026)\end{array}$ \\
\hline$P$-value of F-test & & & \\
\hline DragonYear + DragonYear X Chinese & $0.000^{* * *}$ & $0.000^{* * *}$ & $0.000^{* * *}$ \\
\hline DragonYear + DragonYear X ChMaj & $0.000^{* * *}$ & $0.001^{* * *}$ & $0.000^{* * *}$ \\
\hline DragonYear + DragonYear X Hi-Res & 0.251 & $0.053^{*}$ & 0.882 \\
\hline DragonYear + DragonYear X ModSec & & 0.357 & \\
\hline DragonYear + DragonYear X SocExp & & & 0.716 \\
\hline Observations & 2,688 & 2,688 & 2,688 \\
\hline R-squared & 0.958 & 0.958 & 0.958 \\
\hline Mean of dependent variable (in levels) & 32.2 & 32.2 & 32.2 \\
\hline
\end{tabular}

Notes: Dependent variable is $\log$ (birth rate). All specifications include fully interacted district-ethnicity fixed effects and trends, as used in Column 3 of Table 3 . All regressions are weighted by population. Means of the dependent variable are means across time for the combined population of Malays and Chinese at the level of Peninsular Malaysia. ${ }^{a}$ Modern sector intensity is the share of employed workers in manufacturing, mining, and commerce, or construction out of all employed workers in the district. ${ }^{b}$ Social expenditure is the $\log$ of revised amount of federal public expenditures allocated for education, health, and social and community services from 1976 to 1985 in the state. See Appendix Table A.2 for more details on the state-level variables. Standard errors clustered at the district level are reported in parentheses. ${ }^{*} \mathrm{p}<0.10,{ }^{* *} \mathrm{p}<0.05,{ }^{* * *} \mathrm{p}<0.01$. 
Table 7: Impact of Chinese Lunar Calendar on Stillbirths and Infant Mortality

\begin{tabular}{lccc}
\hline \hline Dependent variable: & \multicolumn{3}{c}{ Log of: } \\
\cline { 2 - 4 } & $\begin{array}{c}\text { Stillbirth } \\
\text { rate } \\
(1)\end{array}$ & $\begin{array}{c}\text { Infant } \\
\text { death rate } \\
(2)\end{array}$ & $\begin{array}{c}\text { Under-1 } \\
\text { mortality rate } \\
(3)\end{array}$ \\
\hline DragonYear & 0.033 & $0.023^{*}$ & $0.024^{*}$ \\
& $(0.022)$ & $(0.014)$ & $(0.013)$ \\
DragonYear X Chinese & -0.039 & $-0.046^{*}$ & $-0.050^{* *}$ \\
& $(0.044)$ & $(0.024)$ & $(0.022)$ \\
P-value of F-test: & & & \\
$\quad$ DragonYear + DragonYear X Chinese & 0.887 & 0.392 & 0.276 \\
& & & \\
Observations & 2,688 & 2,688 & 2,686 \\
R-squared & 0.781 & 0.833 & 0.859 \\
Mean of dependent variable (in levels) & 14.2 & 25.0 & 39.2 \\
\hline \hline
\end{tabular}

Notes: All specifications include fully interacted district-ethnicity fixed effects and trends, as used in Column 3 of Table 3. All regressions are weighted by population. Means of the dependent variables are averaged across Peninsular Malaysia across time for the combined Malay and Chinese population. Standard errors clustered at the district level are reported in parentheses. ${ }^{a}$ Under-1 mortality rate is the number of infant deaths and stillbirths per 1000 live births. ${ }^{*} \mathrm{p}<0.10,{ }^{* *}$ $\mathrm{p}<0.05,{ }^{* * *} \mathrm{p}<0.01$. 
8 Appendix Tables 


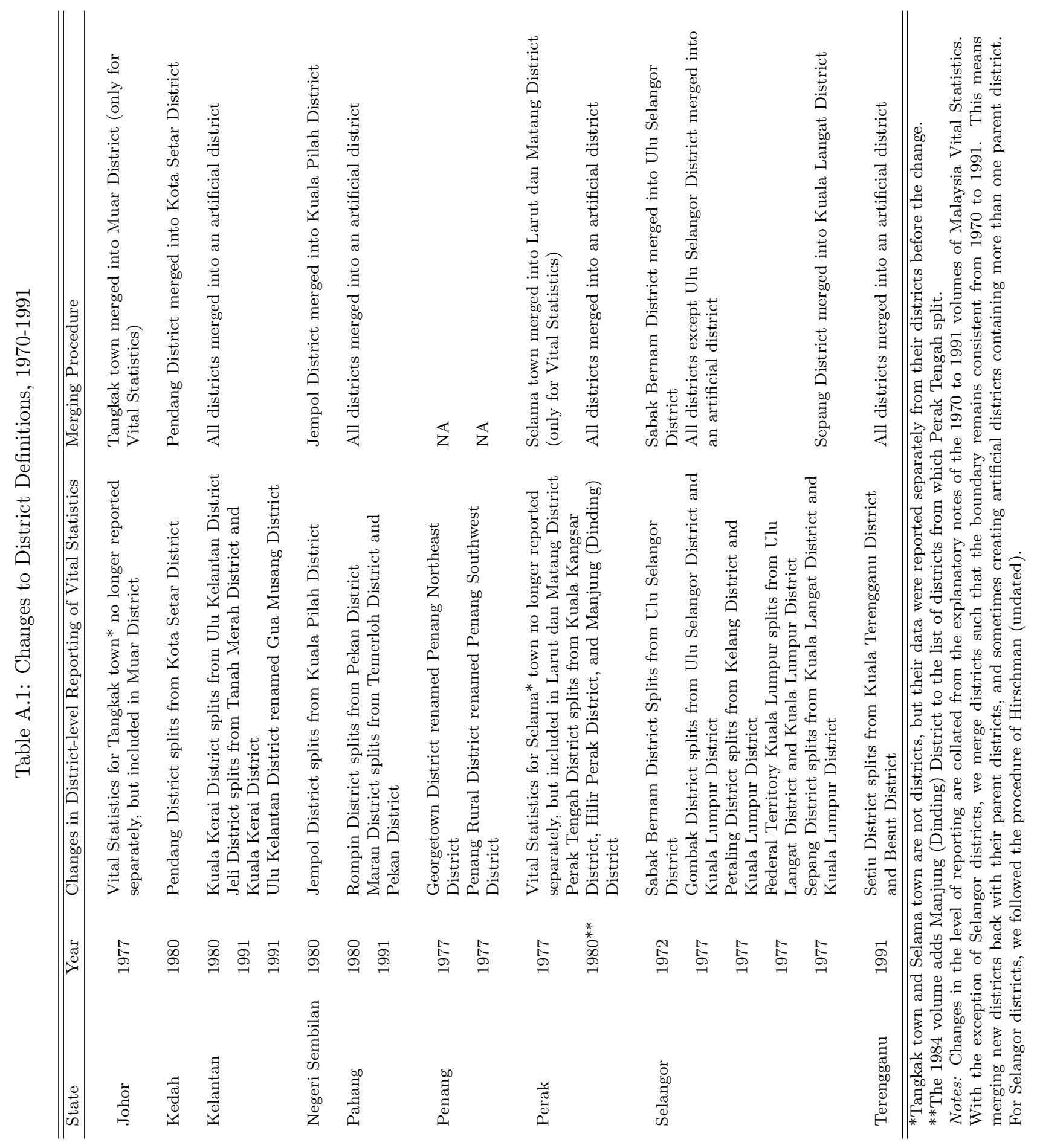




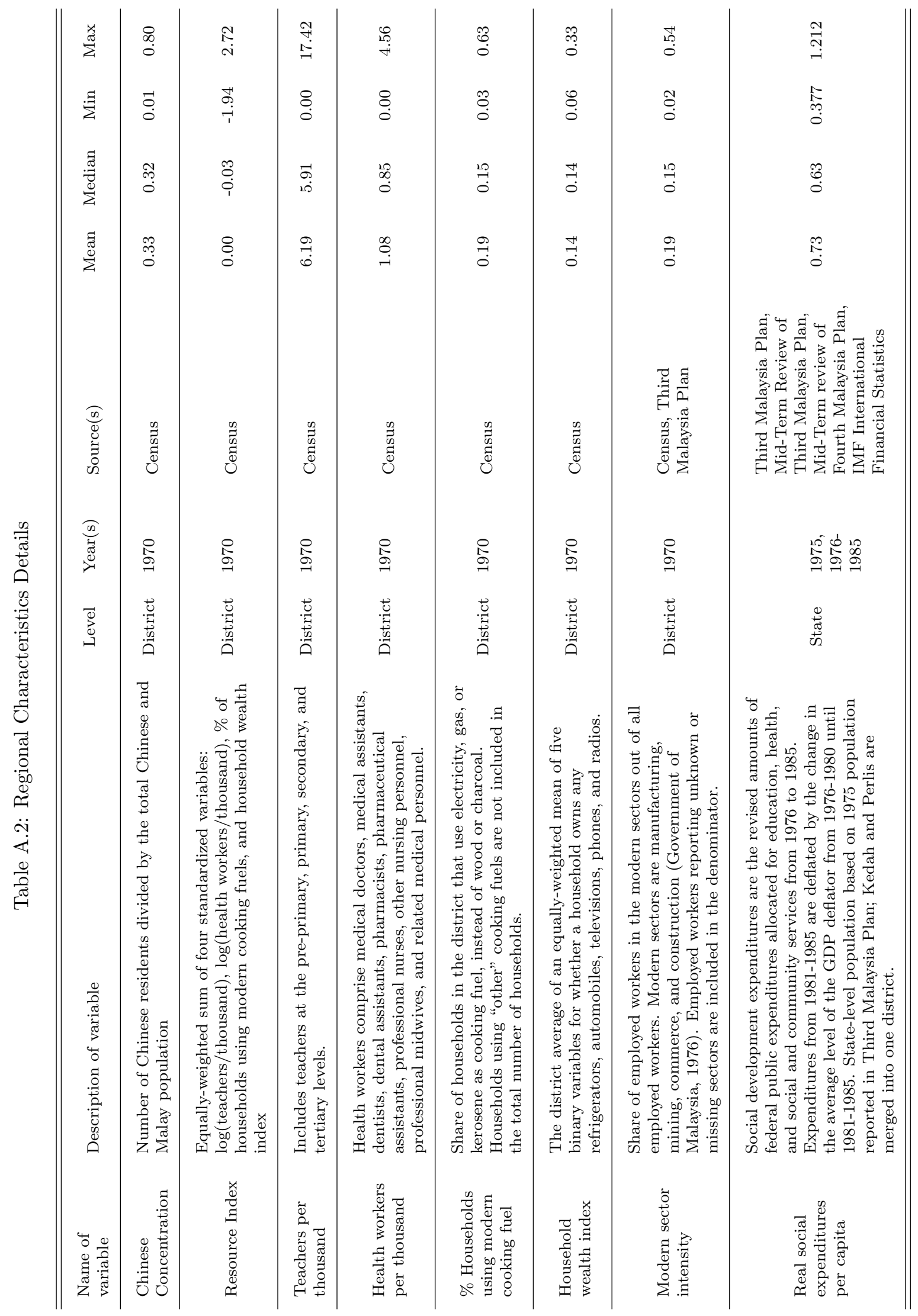


Table A.3: Impact of Chinese Lunar Calendar on Birth Rates, Additional Robustness Checks

\begin{tabular}{|c|c|c|c|c|c|}
\hline & $\begin{array}{c}\begin{array}{c}\text { Lead/lag } \\
\text { effects }\end{array} \\
(1)\end{array}$ & $\begin{array}{l}\text { Omitting } \\
\text { lead/lag } \\
\text { years } \\
(2)\end{array}$ & $\begin{array}{l}\begin{array}{l}\text { Boys } \\
\text { only }\end{array} \\
(3)\end{array}$ & $\begin{array}{l}\text { Girls } \\
\text { only } \\
(4)\end{array}$ & $\begin{array}{l}\text { First- } \\
\text { stage } \\
\text { IV } \\
(5) \\
\end{array}$ \\
\hline DragonYear (DY) & $\begin{array}{c}-0.027^{* * *} \\
(0.005)\end{array}$ & $\begin{array}{c}-0.028^{* * *} \\
(0.005)\end{array}$ & $\begin{array}{c}-0.018^{* * *} \\
(0.005)\end{array}$ & $\begin{array}{c}-0.020 * * * \\
(0.005)\end{array}$ & $\begin{array}{c}0.129 * * * \\
(0.010)\end{array}$ \\
\hline DragonYear X Chinese $(\mathrm{Ch})$ & $\begin{array}{c}0.135^{* * *} \\
(0.010)\end{array}$ & $\begin{array}{c}0.128^{* * *} \\
(0.010)\end{array}$ & $\begin{array}{c}0.142^{* * *} \\
(0.009)\end{array}$ & $\begin{array}{c}0.142^{* * *} \\
(0.010)\end{array}$ & \\
\hline DragonYear lead (DY_lead) & $\begin{array}{l}0.000 \\
(0.005)\end{array}$ & & & & \\
\hline DragonYear lead X Chinese & $\begin{array}{c}-0.055^{* * *} \\
(0.008)\end{array}$ & & & & \\
\hline DragonYear lag (DY_lag) & $\begin{array}{c}-0.040 * * * \\
(0.006)\end{array}$ & & & & \\
\hline DragonYear lag X Chinese & $\begin{array}{c}-0.032^{* * *} \\
(0.007)\end{array}$ & & & & \\
\hline $\begin{array}{l}\text { P-value of F-test } \\
\text { DY + DY X Ch }\end{array}$ & $0.000^{* * *}$ & $0.000 * * *$ & $0.000^{* * *}$ & $0.000^{* * *}$ & \\
\hline $\begin{array}{l}\text { DY_lead + DY_lead X Ch } \\
\text { DY_lag + DY_lag X Ch }\end{array}$ & $\begin{array}{l}0.000^{* * *} \\
0.000^{* * *}\end{array}$ & & & & \\
\hline $\begin{array}{l}\text { DY X Boys = DY X Girls } \\
\text { DY X Boys + DY X Ch X Boys } \\
=\text { DY X Girls + DY X Ch X Girls }\end{array}$ & & \multicolumn{4}{|c|}{0.776} \\
\hline Observations & 2,688 & 2,176 & 2,688 & 2,688 & 1,344 \\
\hline R-squared & 0.961 & 0.962 & 0.953 & 0.951 & 0.937 \\
\hline Mean of dep. var. (in levels) & 32.2 & 32.5 & 16.6 & 15.6 & 26.9 \\
\hline
\end{tabular}


Table A.4: Impact of Chinese Lunar Calendar on General Fertility Rates

\begin{tabular}{|c|c|c|c|c|c|}
\hline & $\overline{(1)}$ & 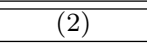 & 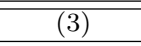 & $\overline{(14)}$ & 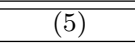 \\
\hline DragonYear & $\begin{array}{c}-0.015^{* * *} \\
(0.005)\end{array}$ & $\begin{array}{c}-0.022^{* * *} \\
(0.005)\end{array}$ & $\begin{array}{c}-0.022^{* * *} \\
(0.005)\end{array}$ & $\begin{array}{c}-0.010^{* *} \\
(0.004)\end{array}$ & $\begin{array}{c}-0.010^{* *} \\
(0.004)\end{array}$ \\
\hline DragonYear X Chinese & $\begin{array}{c}0.131^{* * *} \\
(0.010)\end{array}$ & $\begin{array}{c}0.153^{* * *} \\
(0.009)\end{array}$ & $\begin{array}{c}0.153^{* * *} \\
(0.010)\end{array}$ & $\begin{array}{c}0.179^{* * *} \\
(0.013)\end{array}$ & $\begin{array}{c}0.179^{* * *} \\
(0.013)\end{array}$ \\
\hline \multicolumn{6}{|l|}{$\mathrm{P}$-value of F-test: } \\
\hline DragonYear + DragonYear X Chinese & $0.000^{* * *}$ & $0.000^{* * *}$ & $0.000^{* * *}$ & $0.000^{* * *}$ & $0.000^{* * *}$ \\
\hline Level of observation & \multicolumn{3}{|c|}{ District-year-ethnicity } & \multicolumn{2}{|c|}{ State-month-ethnicity } \\
\hline \multicolumn{6}{|l|}{ Controls: } \\
\hline Region FE and Trend & $\mathrm{X}$ & $\mathrm{X}$ & $\mathrm{X}$ & $\mathrm{X}$ & $\mathrm{X}$ \\
\hline Ethnicity FE & $\mathrm{X}$ & $\mathrm{X}$ & $\mathrm{X}$ & $\mathrm{X}$ & $\mathrm{X}$ \\
\hline Ethn. Trend & & $\mathrm{X}$ & $\mathrm{X}$ & $\mathrm{X}$ & $\mathrm{X}$ \\
\hline Ethn. X Region FE and Trend & & & $\mathrm{X}$ & $\mathrm{X}$ & $\mathrm{X}$ \\
\hline Ethn. X Month X Region FE and Trend & & & & $\mathrm{X}$ & $\mathrm{X}$ \\
\hline Ethn. X Year FE, Region X Year FE & & & & $\mathrm{X}$ & $\mathrm{X}$ \\
\hline Ethn. X Region X Year FE & & & & & $\mathrm{X}$ \\
\hline Observations & 2,688 & 2,688 & 2,688 & 5,126 & 5,126 \\
\hline R-squared & 0.768 & 0.777 & 0.954 & 0.944 & 0.946 \\
\hline Mean of dependent variable (in levels) & 141.2 & 141.2 & 141.2 & 11.7 & 11.7 \\
\hline
\end{tabular}




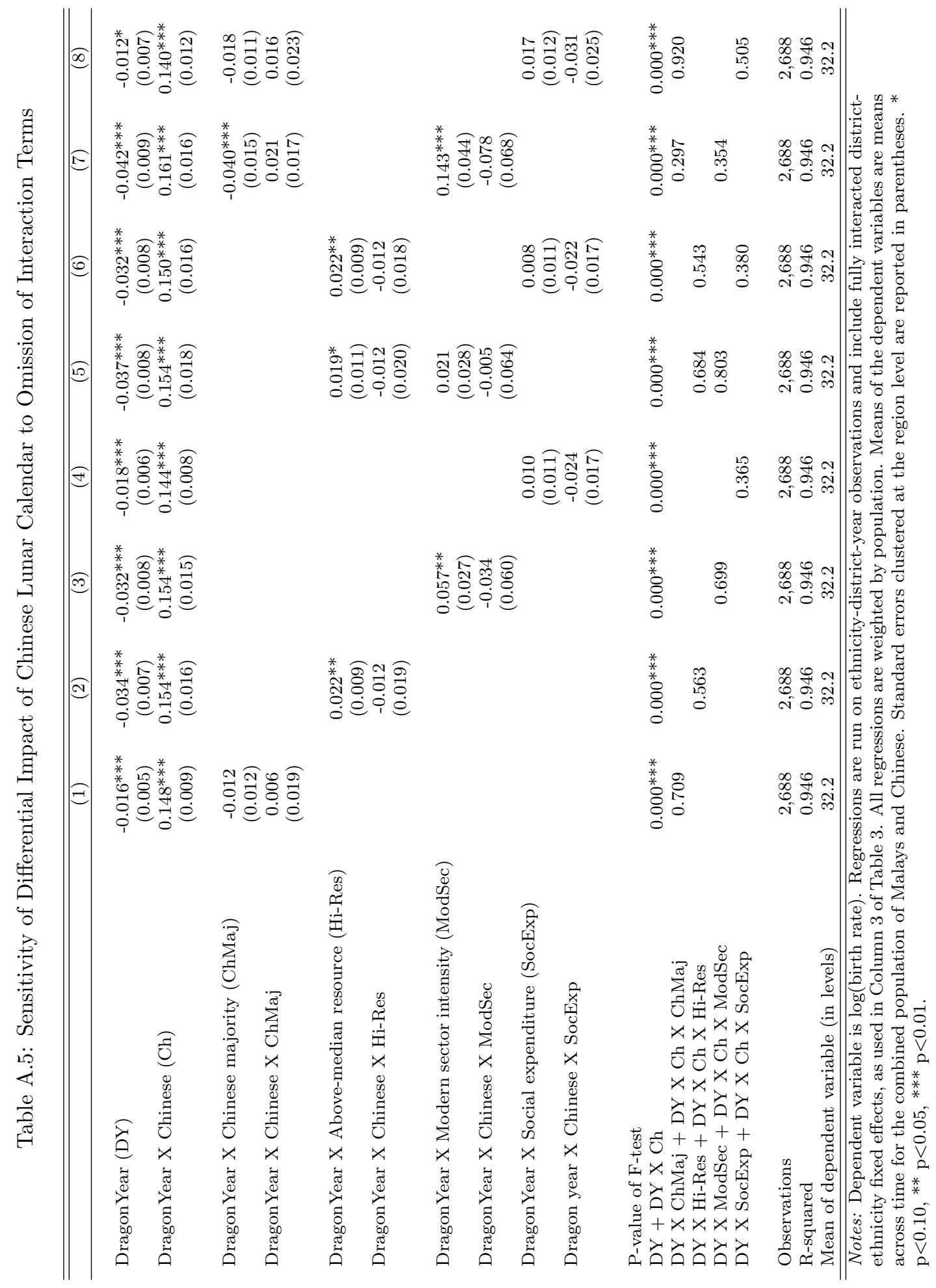


Table A.6: Impact of Chinese Lunar Calendar on Birth Rates, 1991 Census

\begin{tabular}{lccc}
\hline \hline & $(1)$ & $(2)$ & $(3)$ \\
\hline & & & \\
Dragon year & -0.019 & $-0.042^{* *}$ & $-0.043^{* *}$ \\
& $(0.015)$ & $(0.016)$ & $(0.016)$ \\
Dragon year X Chinese & $0.144^{* * *}$ & $0.205^{* * *}$ & $0.207^{* * *}$ \\
& $(0.026)$ & $(0.028)$ & $(0.028)$ \\
& & & \\
P-value of F-test: & & \\
$\quad$ Dragon year + Dragon year X Chinese & $0.000^{* * *}$ & $0.000^{* * *}$ & $0.000^{* * *}$ \\
& & & \\
Observations & 2,688 & 2,688 & 2,688 \\
R-squared & 0.617 & 0.629 & 0.769 \\
Mean of dependent variable (in levels) & 24.9 & 24.9 & 24.9 \\
\hline \hline
\end{tabular}

Notes: Dependent variable is $\log$ (birth rate). Live births are based on the number of individuals from the 1991 census that are born in each year. Regressions are run on ethnicitydistrict-year observations, and controls for each column correspond to the first three columns of Table 3. All regressions are weighted by population. Mean of the dependent variable is means across time for the combined population of Malays and Chinese. Standard errors clustered at the district level are reported in parentheses. ${ }^{*} \mathrm{p}<0.10,{ }^{* *} \mathrm{p}<0.05,{ }^{* * *} \mathrm{p}<0.01$.

Table A.7: Impact of Chinese Lunar Calendar on Birth Selection, Household Characteristics

\begin{tabular}{|c|c|c|c|c|c|c|}
\hline Dependent variable: & Female & $\begin{array}{c}\text { Wealth } \\
\text { index } \\
(2)\end{array}$ & $\begin{array}{c}\text { Both } \\
\text { parents } \\
\text { present } \\
(3) \\
\end{array}$ & $\begin{array}{c}\text { First- } \\
\text { born } \\
(4) \\
\end{array}$ & $\begin{array}{r}\text { Only } \\
\text { child } \\
(5)\end{array}$ & $\begin{array}{c}\text { No. of } \\
\text { siblings } \\
(6)\end{array}$ \\
\hline DragonYear & $\begin{array}{c}-0.004 \\
(0.007)\end{array}$ & $\begin{array}{c}0.003 \\
(0.003)\end{array}$ & $\begin{array}{c}0.021 * * * \\
(0.004)\end{array}$ & $\begin{array}{c}0.001 \\
(0.006)\end{array}$ & $\begin{array}{c}-0.020 * * * \\
(0.003)\end{array}$ & $\begin{array}{c}0.049^{* *} \\
(0.023)\end{array}$ \\
\hline DragonYear X Chinese & $\begin{array}{c}0.002 \\
(0.012)\end{array}$ & $\begin{array}{l}-0.003 \\
(0.005)\end{array}$ & $\begin{array}{l}-0.007 \\
(0.008)\end{array}$ & $\begin{array}{c}0.004 \\
(0.011)\end{array}$ & $\begin{array}{c}0.017^{* * *} \\
(0.007)\end{array}$ & $\begin{array}{c}-0.077^{* *} \\
(0.034)\end{array}$ \\
\hline $\begin{array}{l}\text { P-value of F-test: } \\
\text { DragonYear + DragonYear X Chinese }\end{array}$ & 0.815 & 0.864 & $0.034^{* *}$ & 0.636 & 0.646 & 0.249 \\
\hline $\begin{array}{l}\text { Observations } \\
\text { R-squared } \\
\text { Mean of dependent variable }\end{array}$ & $\begin{array}{c}96,585 \\
0.004 \\
0.493 \\
\end{array}$ & $\begin{array}{c}96,585 \\
0.219 \\
0.630 \\
\end{array}$ & $\begin{array}{c}96,585 \\
0.054 \\
0.830\end{array}$ & $\begin{array}{c}91,562 \\
0.041 \\
0.319 \\
\end{array}$ & $\begin{array}{c}91,562 \\
0.042 \\
0.0701\end{array}$ & $\begin{array}{c}91,562 \\
0.117 \\
2.884\end{array}$ \\
\hline \multicolumn{7}{|c|}{$\begin{array}{l}\text { Notes: Sample includes individuals born from } 1970 \text { to } 1990, \text { taken from the } 1991 \text { census. The sample excludes the } \\
\text { following: individuals who are non-relatives of the household head; individuals residing in single-person, non-relative, } \\
\text { or group quarters type of households; individuals who are heads of single-parent households; and heads or spouses } \\
\text { in households consisting of a single cohabiting couple. Columns } 4-6 \text { further exclude individuals for whom we do not } \\
\text { have information on either parents, and therefore do not have the sibling data. Regressions are run on individual-level } \\
\text { observations and include fully interacted district-ethnicity fixed effects and trends, as used in Column } 3 \text { of Table } 3 \text {. } \\
\text { Standard errors clustered at the household level are reported in parentheses. } * \text { p }<0.10, * * p<0.05, * * * \text { p }<0.01 \text {. }\end{array}$} \\
\hline
\end{tabular}


Table A.8: Impact of Chinese Lunar Calendar on Birth Selection, Parental Characteristics

\begin{tabular}{|c|c|c|c|c|c|c|}
\hline Dependent variable: & $\begin{array}{l}\text { Parental } \\
\text { info } \\
\text { available } \\
(1) \\
\end{array}$ & $\begin{array}{c}\text { Primary } \\
\text { school } \\
(2) \\
\end{array}$ & $\begin{array}{l}\text { Lower } \\
\text { secondary } \\
\text { school } \\
(3) \\
\end{array}$ & $\begin{array}{c}\text { Ever } \\
\text { Worked } \\
(4) \\
\end{array}$ & $\begin{array}{l}\text { High-skill } \\
\text { Occupa- } \\
\text { tion } \\
(5) \\
\end{array}$ & $\begin{array}{c}\text { Modern } \\
\text { Sector } \\
(6) \\
\end{array}$ \\
\hline \multicolumn{7}{|l|}{ Panel A: Mother characteristics } \\
\hline DragonYear & $\begin{array}{c}0.021 * * * \\
(0.004)\end{array}$ & $\begin{array}{l}-0.001 \\
(0.005)\end{array}$ & $\begin{array}{c}-0.001 \\
(0.006)\end{array}$ & $\begin{array}{l}-0.005 \\
(0.006)\end{array}$ & $\begin{array}{c}-0.000 \\
(0.010)\end{array}$ & $\begin{array}{l}-0.004 \\
(0.011)\end{array}$ \\
\hline DragonYear X Chinese & $\begin{array}{c}0.002 \\
(0.007)\end{array}$ & $\begin{array}{c}0.004 \\
(0.010)\end{array}$ & $\begin{array}{c}-0.009 \\
(0.010)\end{array}$ & $\begin{array}{c}0.017 \\
(0.011)\end{array}$ & $\begin{array}{l}-0.007 \\
(0.018)\end{array}$ & $\begin{array}{c}0.013 \\
(0.019)\end{array}$ \\
\hline \multicolumn{7}{|l|}{ P-value of F-test: } \\
\hline $\begin{array}{l}\text { No. of observations } \\
\text { R-squared } \\
\text { Mean of dependent variable }\end{array}$ & $\begin{array}{c}96,585 \\
0.049 \\
0.877\end{array}$ & $\begin{array}{l}84,662 \\
0.123 \\
0.689 \\
\end{array}$ & $\begin{array}{l}84,662 \\
0.165 \\
0.361 \\
\end{array}$ & $\begin{array}{c}84,662 \\
0.057 \\
0.428 \\
\end{array}$ & $\begin{array}{c}25,220 \\
0.069 \\
0.259\end{array}$ & $\begin{array}{l}25,220 \\
0.169 \\
0.406 \\
\end{array}$ \\
\hline \multicolumn{7}{|l|}{ Panel B: Father characteristics } \\
\hline DragonYear & $\begin{array}{c}0.019 * * * \\
(0.004)\end{array}$ & $\begin{array}{l}-0.001 \\
(0.005)\end{array}$ & $\begin{array}{c}0.000 \\
(0.006)\end{array}$ & $\begin{array}{l}-0.000 \\
(0.002)\end{array}$ & $\begin{array}{l}-0.005 \\
(0.005)\end{array}$ & $\begin{array}{c}-0.009 \\
(0.006)\end{array}$ \\
\hline DragonYear X Chinese & $\begin{array}{c}0.003 \\
(0.009)\end{array}$ & $\begin{array}{l}-0.001 \\
(0.009)\end{array}$ & $\begin{array}{c}0.000 \\
(0.011)\end{array}$ & $\begin{array}{c}0.001 \\
(0.003)\end{array}$ & $\begin{array}{l}-0.010 \\
(0.011)\end{array}$ & $\begin{array}{c}0.016 \\
(0.011)\end{array}$ \\
\hline \multicolumn{7}{|l|}{ P-value of F-test: } \\
\hline $\begin{array}{l}\text { Observations } \\
\text { R-squared } \\
\text { Mean of dependent variable }\end{array}$ & $\begin{array}{l}96,585 \\
0.054 \\
0.808\end{array}$ & $\begin{array}{l}78,070 \\
0.099 \\
0.779\end{array}$ & $\begin{array}{l}78,070 \\
0.146 \\
0.417\end{array}$ & $\begin{array}{l}78,070 \\
0.027 \\
0.982\end{array}$ & $\begin{array}{l}73,837 \\
0.055 \\
0.230\end{array}$ & $\begin{array}{l}73,837 \\
0.178 \\
0.363\end{array}$ \\
\hline $\begin{array}{l}\text { Notes: Sample includes individuals born fron } \\
\text { individuals who are non-relatives of the hous } \\
\text { type of households; individuals who are hea } \\
\text { of a single cohabiting couple. Columns } 2-6 \\
\text { information. Columns } 4-6 \text { further restrict the } \\
\text { run on individual-level observations, and incl } \\
3 \text { of Table } 3 \text {. Standard errors clustered at th }\end{array}$ & $\begin{array}{l}970 \text { to } 19 \\
\text { ld head; } \\
\text { of single- } \\
\text { ther excl } \\
\text { mple to in } \\
\text { e fully int } \\
\text { ousehold }\end{array}$ & $\begin{array}{l}\text { ken fror } \\
\text { iduals re } \\
\text { at house } \\
\text { ndividua } \\
\text { uals for } \\
\text { ed distri }\end{array}$ & $\begin{array}{l}1991 \text { cen } \\
g \text { in single } \\
\text {; and hec } \\
r \text { whom w } \\
\text { a the motl } \\
\text { hnicity fix } \\
\text { in parenth }\end{array}$ & $\begin{array}{l}\text { The sa } \\
\text { son, no } \\
\text { r spou } \\
\text { not he } \\
\text { ather) } \\
\text { fects ar } \\
* \text { a }<0\end{array}$ & $\begin{array}{l}\text { xcludes tl } \\
\text { ive, or grc } \\
\text { household } \\
\text { ir mother } \\
\text { loyed. Re } \\
\text { ids as usec } \\
\text { p }<0.05 \text {, }\end{array}$ & $\begin{array}{l}\text { llowing: } \\
\text { quarters } \\
\text { onsisting } \\
\text { father's) } \\
\text { sions are } \\
\text { Column } \\
\text { p }<0.01\end{array}$ \\
\hline
\end{tabular}

